Anita Mularczyk-Budzan ${ }^{1}$

Uniwersytet Papieski Jana Pawła II w Krakowie

\title{
Hieronimowa krytyka pelagianizmu w Dialogu przeciw pelagianom
}

Hieronim, walcząc piórem z pelagianizmem, nie odbiegał zasadniczo od akcentów, jakie w sporze z tą herezją kładli przedstawiciele nurtu tzw. teologii łaski, przede wszystkim Augustyn z Hippony. Autor Wulgaty miał jednak okazję skonfrontować się z Pelagiuszem wcześniej aniżeli Augustyn. Nie stronił od dosadnych wypowiedzi, zwłaszcza w polemikach, a jednocześnie był mistrzem pięknej formy. Być może dlatego, iż wielokrotnie bywał niekonsekwentny w prowadzeniu refleksji teologicznej, Hieronim nie cieszy się wielką popularnością wśród współczesnych patrologów. Z najważniejszych opracowań ogólnych dotyczących teologii Hieronima na uwagę zasługują monografie Johna Normana Davidsona Kelly'ego², Tomasza Jelonka ${ }^{3}$, wstępy do polskojęzycznych tłumaczeń dzieł Hieronimowych autorstwa Wincentego Myszora $^{4}$, Jana Czuja ${ }^{5}$ oraz Moniki Ożóg ${ }^{6}$. Jednak brak w polskojęzycznej pa-

Anita Mularczyk-Budzan, ur. 1986, mgr lic. (praca magisterska „Dialogus contra pelagianos" św. Hieronima jako przykład polemiki dogmatycznej w V wieku). Studentka III roku teologii w cyklu licencjacko-doktoranckim na Uniwersytecie Papieskim Jana Pawła II w Krakowie.

2 J. N. D. Kelly, Hieronim: życie, pisma, spory, przeł. R. Wiśniewski, Warszawa 2003.

3 T. Jelonek, Hieronim, Kraków 2003.

4 W. Myszor, Wstęp, [w:] św. Hieronim, Żywoty mnichów. Dialog przeciw pelagianom, tłum. W. Szołdrski, Warszawa 1973, s. 7-21 (Pisma Starochrześcijańskich Pisarzy, 10).

5 J. Czuj, Przedmowa, [w:] św. Hieronim, Listy, 1 przeł. J. Czuj, Warszawa 1952 [dalej: PAX 1/3], s. 5-22. S. 5-14. 
trystyce opracowań zajmujących się bezpośrednio Hieronimową krytyką pelagianizmu. Pośrednio, lecz bardzo fragmentarycznie o antypelagiańskiej teologii Hieronima wspominają przy omawianiu głównego nurtu kontrowersji pelagiańskiej Arkadiusz Baron ${ }^{7}$ oraz Kazimierz Obrycki ${ }^{8}$.

W niniejszym artykule próbuję ukazać na podstawie pism Hieronima ze Strydonu jego sposób reakcji na zjawisko pelagianizmu, jak i na osobę samego Pelagiusza. Bazę źródłową dla opracowania wymienionej tematyki badawczej stanowią: przede wszystkim traktat Hieronima Dialog przeciw pelagianom ${ }^{9}$, ale także zbiór jego listów ${ }^{10}$ (w tym głównie List $133^{11}$ ), traktat Pelagiusza Komentarz do Listu św. Pawła do Rzymian ${ }^{12}$ oraz traktat Augustyna z Hippony Dzieje procesu Pelagiusza ${ }^{13}$. Przy zastosowaniu metody teologicznej, posiłkując się metodą lingwistyczną i historyczną, chcę najpierw uwypuklić te wątki teologiczne, którymi zajmował się Hieronim w Dialogus contra pelagianos, następnie przejdę do omówienia cech specyficznych jego krytyki pelagianizmu oraz ukazania tej krytyki w kontekście teologii łaski Kościoła zachodniego w pierwszej połowie V wieku.

\section{Główne wątki teologiczne}

Chcąc przyjrzeć się wątkom teologicznym dominującym w dialogu autorstwa Hieronima, warto zwrócić uwagę na księgę trzecią, bowiem ta część polemiki wydaje się najbardziej wartościowa pod względem treści dogma-

7 A. Baron, Spór o Pawła, spór o człowieka czy spór o Boga? Refleksje na marginesie kontrowersji pelagiańskiej, [w:] Pelagiusz, Komentarz do Listu św. Pawła do Rzymian, Kraków 1999, s. 5-167 (Źródła Myśli Teologicznej, 15).

8 K. Obrycki, Koncepcja grzechu pierworodnego u Pelagiusza na podstawie jego „Komentarza do Listu św. Pawła do Rzymian 5, 12-21", [w:] św. Augustyn, Grzech pierworodny. Dzieje procesu Pelagiusza, Kraków 1999, s. 177-185 (Źródła Myśli Teologicznej, 12); K. Obrycki, Wstęp, [w:] św. Augustyn, Grzech pierworodny..., dz. cyt., s. 193-209.

9 Hieronymus Stridonensis, Dialogus adversuspelagianos, k. 495-590, Parisiis 1845 (Patrologia Latina, 23); przekład polski: św. Hieronim, Żywoty mnichów. Dialog przeciw pelagianom, dz. cyt.

10 Św. Hieronim, Listy, 1-3, tłum. J. Czuj, Warszawa 1952-1954.

11 Hieronymus Stridonensis, Epistula 133, k. 1147-1161, Parisiis 1859 (Patrologia Latina, 22).

12 Pelagiusz, Komentarz do Listu św. Pawła do Rzymian, dz. cyt., s. 169-307.

13 Augustyn z Hippony, Grzech pierworodny. Dzieje procesu Pelagiusza, dz. cyt., s. 193-209. 
tycznych. Niemniej jednak trzeba zaznaczyć, że wątki te przenikają całą dysputę, np. w księdze pierwszej, gdzie Hieronim ustosunkowuje się do poszczególnych wypowiedzi pelagiańskich. Jednakże dla lepszej systematyzacji i w celu zachowania równowagi między analizą poszczególnych sekcji dialogu przedmiotem poniższej analizy będzie trzecia część tegoż.

\subsection{Możliwość grzechu po chrzcie}

Przeciwstawione zostają dwa stanowiska - możliwość zachowania stanu bezgrzeszności od momentu chrztu poprzez własne starania (Kritobol) i brak tej możliwości bez połączenia współpracy człowieka z łaską Boga (Attyk). Innymi słowy - Kritobol traktuje chrzest jako pewną gwarancję i bardzo silną pobudkę do niegrzeszenia. Człowiek po chrzcie jest uznany za sprawiedliwego i od tej pory decyduje, mocą swej silnej, nieskalanej woli, o swym bezgrzesznym istnieniu. Mówiąc kolokwialnie, można ująć tę tezę w następujące słowa: „bierze życie w swoje ręce”:

Kritobol: Przyznasz to z pewnością, że ci, którzy otrzymali chrzest Chrystusa, nie mają grzechu; a jeśli są bez grzechu, są sprawiedliwi. Skoro zaś raz sprawiedliwymi się stali, jeżeli usilnie o to się starają, mogą zawsze zachować sprawiedliwość, a dzięki temu unikać wszystkich grzechów ${ }^{14}$.

Kritobol usiłuje przedstawić chrzest jako rodzaj „kasacji” przeszłości, która determinuje pewien constans co do stanu ludzkiej duszy w kwestii możliwości życia bez grzechu. Tabula rasa, którą uczynił Chrystus, a która od momentu chrztu jest zapisywana już bezbłędnie przez zdolnego kaligrafa, jakim jest człowiek.

Jednakże wizja ta spotyka się ze zdecydowanym sprzeciwem ortodoksji, której piewcą jest Attyk:

14 Św. Hieronim, Żywoty mnichów. Dialog przeciw pelagianom, dz. cyt., III.1, s. 168; Liber Tertius, 781, k. 595 (Patrologia Latina, 23). „Certe hoc fateberis Eos, qui Christi baptisma consecuti sunt, non habere peccatum. Et si absque peccato sunt, justos esse. Cumque semel justi fuerint, ei egerint sollicite posse in sempiternum iustitiam custodire, ac per hoc, omne vitare peccatum". 
[...] chrzest przebacza dawne grzechy, ale nie zapewnia na przyszłość utrzymania się w sprawiedliwości; zachowuje się ją pracą, staraniem, pilnością, a zawsze nade wszystko łaskawością Boga ${ }^{15}$.

Można powiedzieć, że kwestia ta - jedna z zasadniczych w polemice - nie zostanie rozstrzygnięta przez zajęcie wspólnego stanowiska, bowiem jeśli chodzi o Pelagiusza, jest on zdeklarowanym kreacjonistą, a przy tym niebywałym optymistą co do możliwości woli człowieka. Neguje możliwość dziedziczenia wraz z naturą Adama (massa Adae) jego grzechu co do ciała. Adam stanowi jedynie zły przykład (exemplum delicti) co do grzeszności i sam stał się wzorem grzechu (forma delicti). Konsekwencją grzechu Adamowego byłaby zatem duchowa śmierć tych, którzy zapatrzeni niejako w przykład (a raczej antyprzykład) Adama dopuścili się grzechu, a jednocześnie wolność od śmierci duchowej dla sprawiedliwych - np. Abrahama, Izaaka czy Jakuba ${ }^{16}$. To przykład (wespół z wolą ludzką) ma wielką siłę, aby ukierunkować człowieka ku dobru bądź złu. Zatem, podsumowując, można stwierdzić, że pogląd iście kreacjonistyczny odnośnie do chrztu i związanego z nim zagadnienia grzechu jawi się następująco: „Grzech Adama zaszkodził jedynie jemu samemu, a nie całemu rodzajowi ludzkiemu. Dzieci nowo narodzone znajdują się w takim stanie, w jakim był Adam przed grzechem. Dzieci, nawet nieochrzczone, mają zapewnione życie wieczne"17. Z tych twierdzeń nietrudno wyprowadzić dalsze poglądy dotyczące możności niegrzeszenia po chrzcie.

Attyk wyprowadza logiczny wniosek odnośnie do postrzegania roli łaski przez Kritobola i zauważa jego niekonsekwencję:

Attyk: Jednakże sprzeciwimy się temu, co ty twierdzisz, że człowiek sam z siebie, mocą swej woli, może być bez grzechu. Jeśli może, to na próżno dołączasz do tego łaskę, której dzięki swym siłom nie potrzebuje. Jeśli zaś nie może ostać się bez grzechu bez łaski Bożej, to głupio powiedziałeś, że może to, czego nie zdoła ${ }^{18}$.

15 Św. Hieronim, Żywoty mnichów. Dialog przeciw pelagianom, dz. cyt., III.1, s. 168; Liber Tertius, 781, k. 596: ,[...] baptisum praeterita donare peccata non futuram servare justitiam, quae laboreore et industria, ac diligentia, et semper super omnia Dei clementia custoditur".

$16 \quad$ K. Obrycki, Wstęp, dz. cyt., s. 185.

17 A. Baron, Spór o Pawła, spór o człowieka czy spór o Boga? Refleksje na marginesie kontrowersji pelagiańskiej, dz. cyt., s. 18-19.

18 Św. Hieronim, Żywoty mnichów. Dialog przeciw pelagianom, dz. cyt., III. 2, s. 170; Liber Tertius, 783, k. 598-599: „Hoc et nos dicimus, posse Deum quidquid voluerit; et hominem per se et pro- 
Attyk niezmiennie i wytrwale próbuje uzmysłowić adwersarzowi, że ucieka przed nazwaniem po imieniu roli łaski w każdym dążeniu ludzkim, jej nieodzowności, twierdzi, że „czas, przez który człowiek zaraz po chrzcie nie ma grzechu, zawdzięcza się nie niemożliwości człowieka, lecz łasce Boga”19. Kritobol z kolei usiłuje wykazać swą rację poprzez odwołanie się do zagadnienia możliwości i zasadności istnienia przykazań, skoro i tak człowiek nie jest w stanie ich wypełnić. Jednak Attyk zbija stanowczo błędne rozumowanie przeciwnika, twierdząc, że przykazania są możliwe do wypełnienia, jednakże wola ludzka jest na tyle słaba, że ludzie nie czynią tego, co możliwe, i dlatego wszyscy potrzebują Bożego miłosierdzia ${ }^{20}$.

Hieronim w wypowiedzi Attyka formułuje swój zarzut przeciw Pelagiuszowi:

Attyk: Ty bowiem mówisz, że nie ma człowieka bez grzechu, lecz taki być może, gdy ja przeciwnie, opowiadam się za tym, co zaprzeczyłeś, że dzięki łasce Bożej człowiek może być bez grzechu, sam z siebie jednak nie zdoła ${ }^{21}$.

Warto jednak dodać, że w tok rozumowania Hieronima wkrada się pewne nieporozumienie na tle językowym. Ujawnia się ono już w Liście 133, będącym zapowiedzią Dialogu przeciw pelagianom. Otóż w zarzutach kierowa-

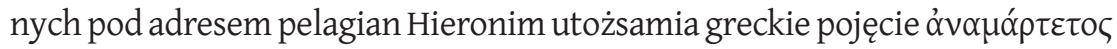
(łac. impeccabilis - niezdolny do grzechu) z łacińskim terminem sine peccato (pol. bez grzechu) ${ }^{22}$, tworząc tym samym wrażenie, iż pelagianie negują istnienie grzechu w człowieku, podczas gdy sam Pelagiusz nie twierdził, że doskonały człowiek jest niezdolny do grzechu, lecz że może żyć bez grzechu o własnych siłach. Potencjalnie jest zdolny zgrzeszyć, jednak silna wola sprawiedliwego pozwala mu żyć bez grzechu.

pria voluntate, quod tu asseris, sine peccato esse non posse. Sin autem potest, frustra nunc jungis et gratiam, qua potens non indigent. Quod si non potest absque Dei gratia, stulte tu dixsti posse quod non potest".

19 Św. Hieronim, Żywoty mnichów. Dialog przeciw pelagianom, dz. cyt., III.3, s. 171.

20 Św. Hieronim, Żywoty mnichów. Dialog przeciw pelagianom, dz. cyt., III.3, s. 171.

${ }_{21}$ Św. Hieronim, Żywoty mnichów. Dialog przeciw pelagianom, dz. cyt., III.3, s. 171; Liber Tertius, 784, k. 599: „Tu enim dicis, non esse hominem sine peccato, sed esse posse, cum e contrario ego tribuam quod negasti, esse hominem sine peccato per Dei gratiam, et tamen per se non posse".

22 Św. Hieronim, List 133, [w:] Św. Hieronim, Listy, 3 Warszawa 1954 [dalej: PAX 3/3], s. $370-371$. 


\subsection{Konieczność pomocy Bożej}

Zagadnienie pomocy Bożej i jej konieczności w każdym ludzkim działaniu jest kolejną istotną kwestią o wymiarze dogmatycznym.

Porozumienie na tej płaszczyźnie również jest niezmiernie trudne, bowiem dotyczy fundamentalnych pojęć, w szczególności pojęciałaski. Kritobol niezmiennie podkreśla wagę ludzkiej wolnej woli, nie usuwając całkowicie łaski (w jego pojęciu), a inaczej ją rozumiejąc, w konsekwencji czego Attyk posądza przeciwnika o zacieranie granic między człowiekiem a Bogiem. Człowiek rości sobie prawo do tego, by być bezgrzeszny jak Bóg:

Attyk: Kto nie może własnymi siłami, swą pracą dojść do Jezusa, to także zdoła uniknąć wszystkich grzechów? I to stale ich unikać i moc Boga sobie przypisywać? Jeśli bowiem jest On „anamartetos” (bezgrzeszny) i ja „,anamartetos”, to jaka jest różnica między mną i Bogiem? ${ }^{23}$.

Attyk uświadamia adwersarzowi, że nawet ludzie święci, sprawiedliwi wznosili głos do Boga, prosili o pomoc, modlili się. W myśl twierdzeń Kritobola musiałyby zniknąć w ogóle z duchowości chrześcijańskiej pojęcia modlitwy, nawrócenia, miłosierdzia Bożego. Attyk prezentuje przeciwnikowi zależność wolnej woli i łaski Boga, rozumianej praktycznie jako Jego pomoc. Jest to istotny moment dialogu, bowiem uwypukla bardzo istotne pojęcia i ich różne pojmowanie przez adwersarzy:

Attyk: Gdzie zaś jest miłosierdzie i łaska, tam wolna wola częściowo ustępuje. Na tym tylko polega, iż chcemy i pragniemy, i przystajemy na to, co się nam podoba. Jednakże zależy to od mocy Boga, abyśmy to, czego pragniemy, nad czym pracujemy, o co się troszczymy, zdołali osiągnąć dzięki Jego pomocy i wsparciu.

Kritobol: Aby nie usuwać wolnej woli, po prostu powiedziałem, iż nie we wszystkich naszych poszczególnych czynnościach odczuwa się pomoc Boga, lecz że ona w ogóle istnieje w łasce, danej jej przez prawo natury ${ }^{24}$.

${ }^{23}$ Św. Hieronim, Żywoty mnichów. Dialog przeciw pelagianom, dz. cyt., III.10, s. 180; Liber Tertius, 792, k. 606: „Qui non potest suis viribus et Lahore venire ad Jesum, quomodo potest omnia Samul peccata vitare? Et vitare in perpetuum, et Dei sibi potentiam nomen assumere? Si

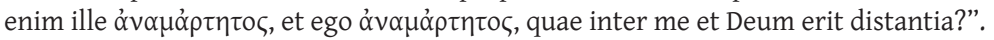

${ }_{24}$ Św. Hieronim, Żywoty mnichów. Dialog przeciw pelagianom, dz. cyt., III.10, s. 181; Liber Tertius, 793, k. 607: „A. Ubi autem misericordia et gratia est, liberum ex parte cessat arbitrium, quod in eo tantum est, ut velimus atque cupiamus, et placitis tribuamus assensum. Jam in Domini po- 
Widać odmienne postrzeganie zasadniczych zagadnień. Można odnieść wrażenie, że podczas gdy Attyk zachowuje równowagę między łaską Boga a wolną wolą człowieka (jednocześnie podkreślając rolę obydwu), Kritobol usiłuje przeforsować swoje stanowisko, w którym łaska traktowana jest marginalnie. Wydaje się, iż pomoc Boga w ujęciu pelagiańskim została raz udzielona człowiekowi (przy akcie stwórczym) i człowiek w swej egzystencji niejako mechanicznie z niej korzysta. Ma jej świadomość jako tej, która tworzy rdzeń człowieczeństwa i uzdalnia człowieka do umiejętnego kierowania swą wolą. Tym samym Bóg nie musi interweniować przy każdej „,błahostce", bowiem uzbroił człowieka w łaskę, której on sam jest dysponentem.

Jest to wątek bardzo złożony i jakikolwiek consensus między dysputantami wydaje się niemożliwy. Inne punkty widzenia, inna optyka powodują, iż w dialogu pojawią się niejednokrotnie sformułowania traktujące o pewnej bezradności Hieronima (Attyka):

Kritobol: Gotowy jestem do słuchania.

Attyk: A ja do mówienia głuchym uszom²5.

\subsection{Możliwość prawdziwej doskonałości na ziemi}

Przedmiotem debaty, a właściwie monologu Attyka w dalszej części księgi trzeciej jest zagadnienie koncentrujące się na możliwości (lub też jej braku) osiągnięcia prawdziwej doskonałości na ziemi. Kritobol dochodzi do głosu po długim wykładzie Attyka, rozpoczynając jednocześnie nowy wątek, dotyczący chrztu dzieci.

Ponownie pojawia się aspekt czasu, który Attyk przywołuje, uświadamiając, że wraz z jego biegiem człowiek nie jest w stanie uciec od słabości. Jedyny, który pozbawiony jest jakichkolwiek grzechów, jest sam Chrystus. Człowiek jest w stanie żyć bez grzechu przez pewien czas, jednakże nie jest to stan niezmienny:

testate est, ut id quod cupimus, quod laboramus ac nitimur, illius ope et auxillio implere valeamus. C. Ego simpliciter dixeram, non in singulis operibus nostris, sed in gratia conditionis et legis, sentiri auxilium Dei, ne liberum frangeretur arbitrium".

${ }_{25}$ Św. Hieronim, Żywoty mnichów. Dialog przeciw pelagianom, dz. cyt., III.10, s. 181; Liber Tertius, 793, k. 607: „C. Paratus sum ad audiencum. A. Et ego ad loquendum surdis auribus”. 
Attyk: To ci już od początku mówiłem, iż od nas zależy grzeszyć lub nie grzeszyć, lub do dobra albo do zła wyciągnąć rękę i tak wola jest zachowana, lecz w miarę co do czasu, z uwzględnieniem słabości ludzkiej. Stała zaś bezgrzeszność zastrzeżona jest Bogu i Słowu, które stawszy się ciałem, nie miało jego braków i grzechów. Do tego, co mogę przez czas krótki, zmuszasz mnie, abym czynił zawsze. Mogę pościć, czuwać, chodzić, czytać, śpiewać, spać, ale czy zawsze? ${ }^{26}$.

Po takich twierdzeniach, wydawałoby się bardzo racjonalnych, Kritobol wysuwa argument dotyczący Pisma Świętego i prawd w nim zawartych. Pismo bowiem wzywa do doskonałości, do doskonałej sprawiedliwości (chociażby przykład błogosławieństw czy powołania Abrahama), po co więc to czyni, skoro jej realizacja nie jest możliwa w ziemskim życiu? Podobnie odnosił się Kritobol do przykazań, gdy prowokacyjnie podawał w wątpliwość konieczność ich istnienia, skoro i tak człowiek nie jest zdolny do ich zachowania, do wypełnienia poleceń Boga:

Kritobol: A dlaczego Pisma święte nas wzywają do doskonałej sprawiedliwości, jak to: „Błogosławieni czystego serca, albowiem oni Boga oglądać będą” (Mt 5, 8)? [...] A to, co Bóg powiedział do Abrahama: „Jam jest Bogiem twoim, staraj się, abyś mi się podobał, bądź bez skazy i nie dawaj powodu do skargi na ciebie, a zawrę przymierze między mną i tobą i niezmiernie cię rozmnożę" (Rdz 17, 1-2). Jeśli się bowiem nie może spełnić to, o czym Pismo świadczy, to daremnie nakazuje, aby tak czyniono ${ }^{27}$.

Kritobol podważa sensowność próśb, nakazów, jeśli i tak są niemożliwe do wypełnienia. $Z$ tego wynika wniosek, że prawa (a tym samym Pismo, które je głosi) są albo niepotrzebne, albo możliwe do wypełnienia, a co za tym

26 Św. Hieronim, Żywoty mnichów. Dialog przeciw pelagianom, dz. cyt., III. 12, s. 182; Liber Tertius, 795, k. 608: „A.: Hoc est quod tibi in principio dixeram, in nostra esse positum potestate, vel peccare, vel non peccare, et vel ad bonum, vel ad malum extendere magnum, ut liberum servetur arbitrium: sed hoc pro modo et tempore et conditione fragilitatis humanae; perpetuitatem autem impecatiae soli reservari Deo, et ei qui Verbum caro factus, carnis detrimenta et peccata non pertulit. Nec quia ad breve possum, coges me ut possim jugiter. Possum jejunare, vigilare, ambulare, legere, psallere, sedere, dormire, numquid in perpetuum?".

27 Św. Hieronim, Żywoty mnichów. Dialog przeciw pelagianom, dz. cyt., III.12, s. 183; Liber Tertius, 795, k. 608-609: „C.: Et quare in Scripturis sanctis ad perfectum justitiam provocamur, u test illud: «Beati mundo corde, quoniam ipsi Deum videbunt (Math. V, 8) [...]»; et Dei loquentis ad Abraham: «Ego sum Deus tuus, piaceto in conspectu meo, et esto sine macula, vel querela, et ponam testamentum meum inter me et te, et multiplicabo te nimis (Gen. XVII, 1, 2)» Si enim non potest fieri quod Scriptura testatur, frustra praecepit ut fieret". 
idzie - istnieją sprawiedliwi, którzy potrafią dochować Bogu nieustannej wierności, do końca swych dni. Attyk jednak neguje to rozumowanie, powołując się na słowa św. Pawła z 1 Kor 13, 9-10: „W części poznajemy i w części prorokujemy”; ,Teraz widzimy niejasno; przez zwierciadło. A gdy przyjdzie to, co jest doskonałe, ustanie to, co jest częściowe"28. Czystość serca, którą mamy dopiero posiąść, teraz posiadamy jedynie w obrazie, cieniu. Bóg kieruje te słowa do wszystkich, nawet do uznawanych za najbardziej sprawiedliwych - Abrahama, Mojżesza. Nawet oni nie byli bez grzechu. Istotny jest argument niemożności usprawiedliwienia przez Prawo. Dopiero łaska Chrystusa jest tym, co daje usprawiedliwienie:

Attyk: [...] dlatego nastąpiła łaska Chrystusa i Ewangelii, że w Zakonie nikt nie mógł się usprawiedliwić? Jeśli więc nikt w Prawie się nie usprawiedliwi, to jakże może w drodze być doskonałym, kto jeszcze idzie i spieszy do celu? [...] Jeśli więc nieskalanym i doskonałym jest ten, kto jeszcze idzie i trzyma się Prawa, to cóż więcej otrzyma, gdy osiągnie cel drogi i Prawa? ${ }^{29}$.

Ewidentnie zatem Attyk neguje możliwość ziemskiej doskonałości. Jest ona bowiem zarezerwowana dla „niebian”. Tu jest czas na pracę i walkę, tam czeka nagroda za pracę i cnotę ${ }^{30}$.

Padają również słowa ostrej krytyki wobec treści listu Pelagiusza do wdowy, w którym zdaniem Hieronima autor daje wyraz swej pysze, ukazując sposób modlitwy kierowanej do Boga przez sprawiedliwego. Na podstawie tego listu można dojść do przekonania, że modlitwa zarezerwowana jest dla nielicznych, doskonałych, świętych; jest rodzajem pewnego luksusu dla elity. Nieścisłością i paradoksem zarazem jest w ogóle ukazanie schematu modlitwy przez Pelagiusza, który przez swoje poglądy niejako neguje jej potrzebę. Bo po co sprawiedliwemu wznoszenie oczu i ust do Boga? Attyk

28 Cytaty z Pisma Świętego podawane za Vulgatą.

29 Św. Hieronim, Żywoty mnichów. Dialog przeciw pelagianom, dz. cyt., III.13, s. 185; Liber Tertius, 797, k. 610: „A.: [...] ideo Christi et Evangelii gratami successisse, quia in lege nemo justificari potuit? Si autem [al. ergo] in lege nullus justificatur, quomodo ad perfectum [al. perfectionem] immaculatus est in via, qui adhuc ambulat, et ad calcem venire festinat? [...] Si ergo immaculatus est ille atque perfectus, qui adhuc ambulat in via, et graditur in lege, quid plus habebit ille, qui ad terminum viae legisque pervenit?".

30 Św. Hieronim, Żywoty mnichów. Dialog przeciw pelagianom, dz. cyt., III.13, s. 185. 
wyraźnie kpi z niekonsekwencji adwersarza, a tym samym uznaje jego poglądy za irracjonalne:

Attyk: Po takim wywyższeniu się, po takiej zarozumiałej modlitwie, w której tak zaznaczyłeś swą świętość, a będąc sam głupim, chcesz o niej głupich przekonać, tak kończysz wreszcie: „Proszę Cię, Panie, abyś nade mną się zmiłował”. Jeśli jesteś święty, jeżeliś niewinny i wolny od wszelkiej skazy i ani mową, ani czynem nie zgrzeszyłeś [...], to dlaczego prosisz o miłosierdzie? Czemu się skarżysz i modły zanosisz, będąc świętym, czystym, mając usta niewinne, nieskalane, będąc wolny od jakiegokolwiek kłamstwa, będąc co do mocy podobny do Boga? ${ }^{31}$.

Attyk piętnuje postawę Kritobola i porównuje ją do faryzejskiej (w kontekście modlitwy celnika). Ponadto podaje przykład modlącego się Chrystusa, jak również apostołów. Modlitwa Pańska, jak przekonuje Attyk, nie jest odmawiana w postawie fałszywej pokory, ale w przeświadczeniu o ludzkiej słabości, poczuciu winy, lęku o siebie ${ }^{32}$.

Zamykając dyskusję, kieruje w stronę przeciwnika ciętą ripostę:

Attyk: Apostołowie upokarzają się, aby byli wywyższeni. Uczniowie twoi się wynoszą, aby upadli ${ }^{33}$.

\subsection{Chrzest dzieci}

Problem chrztu dzieci wiąże się z zagadnieniem grzechu jako takiego i ponownie bardzo dobitnie ukazuje kreacjonistyczne zapatrywania Pelagiusza (Kritobola):

Kritobol: Proszę cię, powiedz, czym dzieciątka zgrzeszyły? [...]. Grzeszyć nie mogą, a mogą zginąć. [...] ci przynajmniej są bez grzechu, którzy grzeszyć nie mogą.

Attyk: Zgadzam się na to, jeśli w imię Chrystusa zostali ochrzczeni, ale nie przystaję na to, co powiedziałeś, że człowiek może być bez grzechu, jeśli zechce. One (dzieci)

31 Św. Hieronim, Żywoty mnichów. Dialog przeciw pelagianom, dz. cyt., III.14, s. 187; Liber Tertius, 799, k. 612: „A.: [...] Et post tantum tumorem, orantisque jactantiam et confidentiam sanctitatis, quasi stultus stultis persuadere conaris, ut in extremo dicas: Quibus tibi ut mihi miserearis preces fundo. Si sanctus es, si innocens, si ab omni sorde purgatus, si nec sermone, nec opera peccasti [...] quomodo misericordiam deprecaris, ut videlicet plangas te, et fundas preces, quia sanctus et purus es te innecens immaculatisque labiis, et ab omni liber mendacio, Dei similis potestati?".

${ }_{32}$ Św. Hieronim, Żywoty mnichów. Dialog przeciw pelagianom, dz. cyt., III.15.16, s. 188-189.

33 Św. Hieronim, Żywoty mnichów. Dialog przeciw pelagianom, dz. cyt., III.16, s. 189; Liber Tertius, 801, k. 614: „A.: A postoli humiliantur, ut exaltentur. Discipuli tui elevantur, ut corruant”. 
bowiem ani chcą, ani nie mogą grzeszyć; są bez żadnego grzechu, dzięki łasce, jaką przy chrzcie otrzymały.

[...]

Kritobol: A co one zawiniły? Czy jest rozwiązywany, kto nie jest związany? ${ }^{34}$.

W odpowiedzi Attyk powołuje się na św. Pawła i jego List do Rzymian 5, 14: „Śmierć panowała od Adama aż do Mojżesza i nad tymi, którzy nie zgrzeszyli na podobieństwo Adama, który jest figurą przyszłego". Twierdzi ponadto, że wszyscy ludzie są winni, czy to z racji pochodzenia od swego dawnego przodka, czy to z powodu własnych win. „Kto jest dzieckiem, pozbywa się przy chrzcie więzów, jakie po ojcu zasięgnął"35.

Aby poprzeć dodatkowo swe stanowisko, sięga po opinię Cypriana, biskupa Kartaginy, którego pisma nie były obce Pelagiuszowi:

Jeśli jednak tym, którzy dopuścili się najcięższych win i wiele poprzednio przeciw Bogu popełnili grzechów, o ile potem uwierzyli, nie odmawia się chrztu i łaski, to o ileż bardziej nie należy w tym przeszkadzać nowo narodzonemu dziecięciu, które nie popełniło żadnego grzechu, lecz tylko przy pierwszym swym narodzeniu zostało dotknięte zarazą dawnej śmierci, ponieważ jak Adam zostało urodzone w ciele. Już z tego względu łatwiej można otrzymać przebaczenie grzechów, że obciążają je nie własne, lecz cudze grzechy ${ }^{36}$.

Kończąc dialog, Hieronim powołuje się na pisma biskupa Hippony Augustyna, niekwestionowanego autorytetu, i zaleca ich lekturę, bowiem

34 Św. Hieronim, Żywoty mnichów. Dialog przeciw pelagianom, dz. cyt., III.17.18, s. 190-191; Liber Tertius, 801-802, k. 614-615: „C.: Oro te, quid infantuli peccavere? [...] Peccare non possunt, et possunt perire [...] Hoc dico, concedas mihi saltem eos esse sine peccato, qui peccare non possunt.; A.: Concedam si in Christo fuerint baptizati, nec illico me tenebis in assensum sententiae tuae, qua dixisti posse hominem sine peccato esse si velit; isti enim nec possunt, nec volunt: sed sine ullo peccato per Dei gratiam sunt, quam in baptismo susceperunt. C.: Cogis me, ut ad invidiosum illud veniam et dicam tibi: Qui enim peccaverunt? ut statim in me populorum lapides conjicias, et quem viribus non potes, voluntate interficias".

35 Św. Hieronim, Żywoty mnichów. Dialog przeciw pelagianom, dz. cyt., III.18, s. 192.

36 Św. Hieronim, Żywoty mnichów. Dialog przeciw pelagianom, dz. cyt., III.18, s. 192; Liber Tertius, 804, k. 616: „A.: Porro autem si etami gravissimis delictoribus, et in Deum multo ante peccantibus, cum postea crediderint, remissie peccatorum datur, et a baptismo atque gratia nemo prohibetur, quanto magis prohiberi non debet infant, qui recens natus nihil peccavit, nisi quo secundum Adam carnaliter natus contagium mortis antiqua prima nativitate contraxit? qui ad remissionem peccatorum accipiendam, hoc ipso facilius accedit, quod illi remittuntur non propria, sed aliena peccata!". 
"mąż święty i wymowny biskup Augustyn ${ }^{37 ” ~ j u z ̇ ~ w i e l e ~ m i e j s c a ~ p o s ́ w i e ̨ c i ł ~}$ problemowi chrztu dzieci, również w kontekście herezji pelagiańskiej, a on nie chce być posądzony o „noszenie drzewa do lasu” (jak mawiał Horacy) ${ }^{38}$. Autorytet Augustyna powinien być wystarczającym gwarantem wiarygodności Hieronimowych tez.

Ostatecznie jedynym rozwiązaniem, które pelagianie, jeśli nie zmienią swych poglądów, winni zastosować, jest według Hieronima zmiana Credo i utworzenie jego własnej wersji, w której będą głosić chrzest dzieci dla niebiańskiego królestwa lub dla odpuszczenia grzechów na podobieństwo grzechu Adama. Oprócz zmodyfikowania na własne potrzeby wyznania wiary pelagianie winni odwołać się do „swego kochanka” ${ }^{39}$ (Orygenesa), który twierdził, że chrzest gładzi grzechy dawne, popełnione w niebie. Postawieniem kropki nad „,i” jest jednoznaczne podkreślenie, iż Orygenes i jego nauka odgrywała niemałą rolę w poglądach pelagiańskich (przynajmniej w mniemaniu Hieronima) ${ }^{40}$ : „Jak i w innych rzeczach trzymacie się jego powagi, tak i co do tego kierujcie się jego błędem" ${ }^{41}$.

To zdanie, kończące Dialog przeciw pelagianom, zdaje się brzmieć jak swoiste „błogosławieństwo” na dalszą drogę, prowadzącą pelagian przez gąszcz licznych odstępstw od ortodoksji. Ironia i przestroga specyficznego „błogosławieństwa" są tylko (albo aż!) tym, co mógł przekazać pseudotraducjanista $^{42}$ zdeklarowanemu kreacjoniście.

${ }_{37}$ Św. Hieronim, Żywoty mnichów. Dialog przeciw pelagianom, dz. cyt., III.19, s. 192; Liber Tertius, 804, k. 616: „vir sanctus et eloquens episcopus Augustinus”.

38 Św. Hieronim, Żywoty mnichów. Dialog przeciw pelagianom, dz. cyt., III.19, s. 193; Liber Tertius, 805, k. 617: Horatii: „In silvam ne ligna”.

39 Liber Tertius, 806, k. 618: „A.: [...] amasium vestrum”.

40 Św. Hieronim, Żywoty mnichów. Dialog przeciw pelagianom, dz. cyt., III.19, s. 193.

${ }^{41}$ Św. Hieronim, Żywoty mnichów. Dialog przeciw pelagianom, dz. cyt., III.19, s. 193; Liber Tertius, 806, k. 618: „A.: [...] ut cujus in caeteris auctoritate ducimini, etami in hac parte terrorem sequamini"; por. też: św. Hieronim, List 124, PAX 3/3, s. 235-252.

${ }^{42}$ Hieronim tak naprawdę przejawiał skłonność do poglądów kreacjonistycznych (Commentarius in Ecclesiasten, 12, 7; Apologia adversus libros Rufini 2, 8-10; Epistulae 126,1) i nie opowiadał się za żadną ze stron sporu, a jedynie prezentował pięć tez. Wydaje się, że Hieronim stał się traducjanistą na potrzeby Dialogus contra pelagianos: aby odeprzeć argument Pelagiusza, jakoby Adam był jedynie exemplum delicti, a w głębi był nadal „,wyznawcą" kreacjonizmu; jak również by nie dawać powodu do skojarzeń z herezjarchą. Można bowiem zauważyć niepokój, chociażby u Augustyna, który martwiąc się poglądami kreacjonistycznymi Hieronima, wystosowuje 


\section{Specyfika ujęcia tematyki pelagiańskiej przez Hieronima}

By móc zwrócić uwagę na elementy specyficzne dla Hieronima, warto znaleźć punkt odniesienia, bowiem nic tak nie ujawnia cech człowieka jak relacja „z" - z drugim człowiekiem, problemem, zjawiskiem. Uzasadnione wydaje się zatem prześledzenie pokrótce kontaktów Hieronima z Augustynem. Ci dwaj wielcy ojcowie Kościoła zachodniego byli mocno zaangażowani w walkę z pelagianizmem, jednak czynili to w nieco odmienny sposób. Jeden cel, czasem różne formy komunikacji i wyrażania swych racji. Ukazanie kontaktów między Hieronimem i Augustynem (głównie korespondencyjnych) pozwoli ukazać różnice ich temperamentów, co z kolei przekładać się będzie na ich odniesienie do herezji pelagiańskiej i samego Pelagiusza. Historia korespondencji była bardzo burzliwa i skomplikowana, bowiem listy albo nie dochodziły, albo też trafiały do innego adresata czy też zostały doręczone z dużym opóźnieniem, co z kolei wywoływało mnóstwo niedomówień i komplikacji w wymianie myśli. To natomiast powodowało duże rozdrażnienie Hieronima, który bardzo źle znosił słowa krytyki, a w każdej zawiłości doszukiwał się drugiego dna.

W połowie lat dziewięćdziesiątych IV wieku zaczęła się historia epistolograficznej znajomości Augustyna z Hieronimem. Pobudką do rozpoczęcia korespondencji była chęć nawiązania przez Augustyna kontaktu ze słynnym uczonym i jednocześnie krytyka niektórych poglądów Hieronima (przyznawanie prymatu hebrajskiemu oryginałowi Starego Testamentu, sposób interpretacji fragmentu Listu do Galatów $)^{43}$. List ${ }^{44}$ nie dotarł do adresata, w związku z czym Augustyn wystosował kolejne pismo ${ }^{45}$, jednak nieszczęśliwym trafem zamiast do Betlejem dotarło ono do Rzymu. Tam list wzbudził niemałą sensację i był nie lada gratką dla przeciwników Hieronima, a jednocześnie powodem do niezadowolenia i konsternacji dla jego stronni-

do niego listy, w których rozpatruje m.in. kwestie pochodzenia duszy, grzechu pierworodnego, chrztu dzieci. Por. J. N. D. Kelly, Hieronim: życie, pisma, spory, dz. cyt., s. 362-363; św. Hieronim, List 131, List 132, PAX 3/3, s. 330-367.

$43 \quad$ J. N. D. Kelly, Hieronim: życie, pisma, spory, dz. cyt., s. 302.

${ }_{44}$ Augustyn z Hippony, List 28, [w:] Augustyn z Hippony, Listy, tłum. W. Eborowicz, Pelplin 1991, s. 211-215; w zbiorze listów Hieronima to List 56, PAX 1/3, s. 391-396.

45 Augustyn z Hippony, List 40, [w:] Augustyn z Hippony, Listy, dz. cyt., s. 270-273; św. Hieronim, List 67, PAX 2/3, s. 94-100. 
ków. Jak nietrudno się domyślić, Hieronim nie był zachwycony tym faktem. Wrodzona podejrzliwość i skłonność do łatwego obrażania się doprowadziły go do wniosków, iż owa korespondencja miała na celu jego kompromitację poprzez jej szerokie upublicznienie. Jednocześnie podejrzewał Augustyna o chęć zdyskredytowania jego osoby i zyskanie sławy kosztem adresata ${ }^{46}$.

Tymczasem sam nadawca, oczekujący rzeczowej, teologicznej wymiany zdań, ze zdziwieniem obserwował reakcje, które wywołała jego „niepozorna" i pełna kultury korespondencja ${ }^{47}$. Doszła do niego wieść, iż jest oskarżany w Betlejem o napisanie księgi przeciw Hieronimowi, którą rzekomo świadomie wysłał do Rzymu ${ }^{48}$. Augustyn postanowił zatem załagodzić powstałe nieporozumienie i niemałą irytację Hieronima, jak i jego środowiska, wysyłając łagodną i rzeczową korespondencję, w której na plan pierwszy zdają się wysuwać pokora i szacunek dla poglądów i osoby „Najdroższego i wielce umiłowanego Pana (Hieronima)" ${ }^{49}$. Postawę Augustyna najpełniej wyrażają słowa zawarte w owym liście: „Może w niektórych moich pismach znajdują się wypowiedzi, z których wynika, że myślałem inaczej niż Ty, ale przecież nie wyraziłem tam zarzutu przeciw Tobie, lecz tylko sformułowałem własny pogląd"50.

$46 \quad$ J. N. D. Kelly, Hieronim: życie, pisma, spory, dz. cyt. s. 302.

47 Augustyn z Hippony, List 28: „Augustyn pozdrawia najszczerszej czci, miłości, szacunku i przywiązania godnego Pana, Brata i Współkapłana, Hieronima. [...] Nigdy nikt nie znał w równej mierze bliźniego z oblicza, jak ja Ciebie z Twoich studiów w Panu, którym się oddajesz ze spokojem i weselem, oraz z Twych prawdziwie szlachetnych ćwiczeń. Choć więc ogromnie pragnę Cię poznać, to jednak wciąż mi brak tej drobnej cząstki Ciebie, mianowicie obecności cielesnej”; List 40: „mowa bowiem takiego jak Ty męża nie wydaje się zbyt długa, ilekolwiek by czasu zajęła. [...] Dlatego proszę Cię, zacznij ze mną tę listowną wymianę myśli, ażeby odległość, która nas dzieli, nie mogła nas rozłączyć, chociaż w Panu jesteśmy zjednoczeni duchowo nawet wtedy, gdy milczymy odłożywszy pióro", [w:] Augustyn z Hippony, Listy, dz. cyt., s. 270.

48 J. N. D. Kelly, Hieronim: życie, pisma, spory, dz. cyt., s. 303.

49 Augustyn z Hippony, List 67, [w:] Augustyn z Hippony, Listy, dz. cyt., s. 382-383; św. Hieronim, List 101, PAX 2/3, s. 352-353; por. Hieronim ze Strydonu, Listy, 3, wstęp i oprac. na podstawie tłum. J. Czuja M. Ożóg, tekst łac. przygotował H. Pietras, Kraków 2011, s. 112 (Źródła Myśli Teologicznej, 61): „Boga naszego biorę na świadka, że tego nie uczyniłem, a jeśli może znajduje się w niektórych pismach moich coś takiego, z czego wynika, że myślałem inaczej niż ty, to przecież wyraziłem tam nie zarzut przeciw tobie, lecz tylko własny pogląd” („Deum nostrum testor, hoc me non fecisse, sed si forte aliqua in aliquibus scriptis meis reperiuntur, in quibus aliter aliquid quam tu sensisse reperiar, non contra te dictum, sed quo mihi videbatur, a me scriptum esse, puto te debere cognoscere: aut si cognosci non potest, credere").

50 Augustyn z Hippony, List 67, [w:] Augustyn z Hippony, Listy, dz. cyt., s. 382-383. 
Istotny wydaje się fakt, iż Augustyn zdecydowanie oddziela poglądy od osoby. Szacunek, jaki przysługuje każdemu człowiekowi, jest kwestią oczywistą, na co poglądy, jakiekolwiek by były, nie mają wpływu. Nie da się ukryć, iż Hieronim miał z tym niemałe kłopoty, niezależnie od tego, z kim prowadził dyskurs, czy był to „prawdziwie święty Pan i błogosławiony Ojciec Augustyn ${ }^{51}$ ”, czy „nauczyciel przewrotnej zasady52” - Pelagiusz. Wyrażenie odmiennych poglądów było dlań niemal równoznaczne z zamachem na jego osobę. Toteż list będący odpowiedzią na pokorne pismo Augustyna, mimo iż w formie uprzejmy, ukazujący serdeczność, faktycznie zawiera pewną dozę podejrzliwości ${ }^{53}$. Nieufność spowodowana była niewątpliwie krytyką jego poczynań egzegetycznych i jej upublicznieniem w opiniotwórczym ośrodku, jakim był Rzym ${ }^{54}$. Co istotne, list ten ujawnia znamienny rys charakteru Hieronima: w przeciwieństwie do Augustyna z jego pokorą i chęcią poznania odmiennych opinii, powstrzymuje się od wszelkich komentarzy na temat twórczości Augustyna, oczekując od biskupa Hippony tego samego.

Z jednej strony twierdzi, że „nie jest na tyle nierozsądny, by czuł się dotknięty odmiennością objaśnień do Pisma Świętego ${ }^{55}$ ", lecz zaraz potem dość niekonsekwentnie dodaje: „Jeśli jednak [...] swego worka nie widzimy, a cudzy węzełek podpatrujemy, to taka przyjaźń naprawdę zasługuje na naganę" ${ }^{56}$. Odwołuje się również do wieku Augustyna, sugerując, iż posiada dużo mniejsze doświadczenie od niego: „[...] powinieneś darzyć miłością tego, który cię kocha, i w dziedzinie Pisma Świętego ty, człowiek młody, nie prowokować mnie - starca" ${ }^{57}$. Po uszczypliwych wtrąceniach i sarkastycznych komentarzach Hieronim ukazuje w liście swą drugą twarz pokorne-

51 Św. Hieronim, List 102, PAX 2/3, s. 353; Augustyn z Hippony, List 68, [w:] św. Hieronim, Listy, dz. cyt., 1991, s. 383.

52 Św. Hieronim, List 133, PAX 3/3, s. 384.

53 Św. Hieronim, List 102, PAX 2/3, s. 353-355; Augustyn z Hippony, List 68, [w:] św. Hieronim, Listy, dz. cyt., s. 383-385.

54 J. N. D. Kelly, Hieronim: życie, pisma, spory, dz. cyt., s. 303.

55 Św. Hieronim, List 102, PAX 2/3, s. 354.

56 Św. Hieronim, List 102, PAX 2/3, s. 354; por. Hieronim ze Strydonu, Listy, 3, dz. cyt., s. 115, łac.: „Sed illa est vera inter amicos reprehensio, si nostram peram non videntes, aliorum, iuxta Persium, manticam consideremus".

${ }_{57}$ Św. Hieronim, List 102, PAX 2/3, s. 354. Por. Hieronim ze Strydonu, Listy, 3, dz. cyt., s. 115 , łac.: „Superest, ut diligas diligentem te; et in Scripturarum campo, iuvenis senem non provoces”. 
go, doświadczonego człowieka, służącego pomocą i otwartego (o, ironio!) na zdanie Augustyna: „[...] obym zasłużył na twe uściski i przez wzajemną rozmowę albo ciebie czegoś nauczył, albo sam się dowiedział" ${ }^{58 "}$.

Ciekawą kwestią rzucającą światło na specyfikę twórczości i osoby Hieronima jest udawanie niepewności co do Augustynowego autorstwa listu, służące ominięciu niewygodnego tematu. Hieronim miał bowiem świadomość, że argumentacja Augustyna dotycząca interpretacji fragmentu Listu do Galatów jest interpretacją trafną, jednakże nie był w stanie publicznie przyznać się do błędu. Miał nadzieję, że problem zostanie przemilczany i zapomniany ${ }^{59}$. Podobną zresztą taktykę stosował w Dialogu przeciw pelagianom, uciekając się do rozmaitych chwytów retorskich, odwracając uwagę przeciwnika od niewygodnej dlań kwestii i przechodząc do zagadnień, w których wykazywał biegłość ${ }^{60}$.

Korespondencja dwu wielkich ojców zawierała antagonistyczne rysy: z jednej strony pokorny Augustyn, z drugiej - przewrażliwiony i nader ostry Hieronim. Wyrazem tych skrajnych postaw są choćby kolejne listy - 105. Hieronima i 73. Augustyna (który biskup Hippony wysłał przed otrzymaniem cierpkiego listu Hieronima). List $105^{61}$ pełen jest, w większym nawet stopniu aniżeli List 102, rozmaitych insynuacji, nieufności oraz agresywnego tonu ${ }^{62}$..Jako przeciwieństwo tego tekstu można wskazać wspomniane pismo Augustyna ${ }^{63}$, będące ,jednym z jego najbardziej wzruszających i najpiękniejszych tekstów" ${ }^{\prime 64}$.Z wielką pokorą Augustyn daje do zrozumienia, iż widocznie jest winien, skoro Hieronim przyjął wobec niego taką postawę. W sobie raczej dopatruje się winy niźli w swym przyjacielu. Pragnie siąść u stóp Hieronima, by móc się od niego uczyć65.

58 Św. Hieronim, List 102, PAX 2/3, s. 355. Por. tamże: „[...] utinam mereremur complexus tuos, et collatione mutua vel doceremus aliqua, vel disceremus".

59 J. N. D. Kelly, Hieronim: życie, pisma, spory, dz. cyt., s. 304.

60 Św. Hieronim, Żywoty mnichów. Dialog przeciw pelagianom, dz. cyt., s. 79.

61 Św. Hieronim, List 105, PAX 2/3, s. 360-363.

${ }^{62}$ Św. Hieronim, List 105, PAX 2/3, s. 363: „[...] prowokujesz starca, wyzywasz milczącego i wydaje się, że się chełpisz swą erudycją"; Hieronim ze Strydonu, Listy, 3, dz. cyt., s. 122, łac.: „[...] provocas senem, tacentem stimulas, videris iactare doctrinam".

63 Augustyn z Hippony, List 73, [w:] Augustyn z Hippony, Listy, dz. cyt., s. 395-401; św. Hieronim, List 110, PAX 3/3, s. 10-18.

${ }^{64}$ J. N. D. Kelly, Hieronim: życie, pisma, spory, dz. cyt., s. 306.

65 Augustyn z Hippony, List 73, [w:] Augustyn z Hippony, Listy, dz. cyt., s. 398-399. 
Widać zatem, jak odmienne postawy prezentują ci dwaj wielcy ojcowie Zachodu. Biskup Hippony uświadomił sobie, jak wrażliwy na swoim punkcie był Hieronim i jak dalece posuniętej delikatności wymagają kontakty z nim. Wyrazem tego było przekazanie korespondencji w ręce biskupa Prezydiusza, by ten pełnił niejako funkcję pośrednika w dyskursie. Aby Prezydiusz orientował się dokładnie, na czym polega problem, Augustyn wręczył mu próbki korespondencji - własny List 40 i List 102 autorstwa Hieronima. Załączył także znamienne uwagi: „Po przeczytaniu łatwo osądzisz. Będąc święcie roztropnym, zarówno moją powściągliwość, którą uznałem za stosowne zachować, jak i jego oburzenie, którego nie na próżno się obawiałem" ${ }^{66}$.Znamienny i przełomowy wydaje się List 115, będący niejako załącznikiem do Listu 112 i reakcją na niesłychanie piękny i czuły List 73, który dotarł do Hieronima już po napisaniu ostrego, a zarazem krótkiego traktatu ${ }^{67}$, gdzie w końcu ustosunkowuje się on do problemów natury teologicznej poruszanych przez Augustyna. Był to „majstersztyk stylu i erudycji, starannie zaplanowany z myślą o publikacji”68. Podczas gdy List 112 pełen jest uszczypliwości i drwin, choćby z pełnionej przez Augustyna posługi biskupa: „Ty, młody i na biskupi tron wyniesiony, nauczaj narody i nowymi afrykańskimi owocami wzbogacaj spichrze rzymskie. Mnie wystarczy w ubożuchnym kąciku klasztoru szeptać ze słuchaczem lub czytelnikiem" "69, List 115 stanowi swego rodzaju kontrast dla wcześniejszego ujęcia.

Widać Augustyn znalazł metodę na Hieronima. Sztuka retorska, nieobca również biskupowi Hippony, połączona z wielką wrażliwością, szacunkiem i pokorą, sprawiła, iż ego Hieronima zostało podbudowane, a serdeczność odpowiedzi nie miała granic: „Proszę cię, wybacz mi ze względu na uczucie wstydu, które tak długo nalegało na odpowiedź, że w końcu nie mogłem mu się oprzeć. W rzeczywistości to nie ja tobie, lecz sprawa spra-

66 Augustyn z Hippony, List 74, [w:] Augustyn z Hippony, Listy, dz. cyt., s. 402; św. Hieronim, List 111, PAX 3/3, s. 18. Por. Hieronim ze Strydonu, Listy, 3, dz. cyt., s. 200, łac.: „Quibus lectis pro tua sancta prudentia facile videbis et modum meum, quem servandum putavi, et motum eius, quem non frustrat timui".

${ }_{67}$ Św. Hieronim, List 112, PAX 3/3, s. 19-40.

68 J. N. D. Kelly, Hieronim: życie, pisma, spory, dz. cyt., s. 308.

${ }_{69}$ Św. Hieronim, List 112, PAX 3/3, s. 40. Por. Hieronim ze Strydonu, Listy, 3, dz. cyt., s. 216, łac.: „Tu qui iuvenis es, et in Pontificali culmine constitutus, doceto populos, et novis Africae frugibus Romana tecta locupleta (locupletato - Migne). Mihi suflicit cum auditore et lectore pauperculo in angulo monasterii susurrare". 
wie odpowiada"70. Wydaje się, że Hieronim spostrzegł, iż to nie ataki ad personam winny być rdzeniem i celem korespondencji, ale rzeczowa i rzetelna dyskusja, wolna od wzajemnych animozji.

Hieronim wyraził ogromne pragnienie podtrzymania przyjaźni z Augustynem: „[...] niech zapanuje między nami prawdziwe braterstwo i niech odtąd w naszych listach miejsce sporów zajmie szczera przyjaźń [...]. Jeśli chcesz, spędzajmy miło czas nad Pismem Świętym, nie sprawiając sobie wzajemnie przykrości"71.

Główny etap korespondencji Augustyna i Hieronima zamknął List 82 $2^{72}$, który autor pisał, mając przed oczyma tak odmienne w treści pisma Hieronima. W tym dość długim liście wydaje się już lekko znużony, a zarazem niezmiennie zaskoczony skłonnością do obrażania się oraz nadwrażliwością przyjaciela $^{73}$. Kończąc pismo, zwraca się z prośbą do adresata: „[...] kierujmy się wzajemnie nie tylko miłością, lecz także swobodą, jaką daje przyjaźńn ${ }^{74 "}$ ".

Na przykładzie przytoczonego obrazu korespondencji nietrudno dostrzec wyraźne różnice cech charakteru, a co za tym idzie, sposobu wyrażania myśli przez Hieronima i Augustyna. Mimo iż Hieronim jawi się tu w mniej przychylnym świetle, warto dodać, że Augustyn był człowiekiem o wiele młodszym, dlatego trudno winić Hieronima, że „nie dostrzegał w nim posągowej postaci, jaką stanie się dla przyszłych pokoleń"75. Mógł w biskupie z Hippony początkowo dostrzegać kogoś, kto chce zachwiać jego autorytetem, ośmieszyć go w oczach wpływowych środowisk. Na początku ich wspólnej drogi chyba żaden nie przypuszczał, że staną niebawem ramię w ramię w walce

70 Św. Hieronim, List 115, PAX 3/3, s. 44; por. św. Hieronim, PAX 3/3, s. 220, łac.: „[...] simulque obsecro, ut ignoscas pudori meo, quod diu ut rescriberem, praecipienti negare non potui. Nec ego tibi, sed causa causae respondit".

${ }_{71}$ Św. Hieronim, List 115, PAX 3/3, s. 44; por. por. św. Hieronim, PAX 3/3, s. 220, łac.: „[...] sit inter nos pura germanitas; et deinceps non quaestionum, sed caritatis ad nos scripta mittamus [...]. In Scripturarum si placet campo sine nostro invicem dolore ludamus".

72 W zbiorze listów Hieronima to List 116, PAX 3/3, s. 44-71.

73 J. N. D. Kelly, Hieronim: życie, pisma, spory, dz. cyt., s. 311.

74 Augustyn z Hippony, List 82, [w:] Augustyn z Hippony, Listy, dz. cyt., 44-71; w zbiorze listów Hieronima to List 116, PAX 3/3, s. 71. Por. Hieronim ze Strydonu, Listy, 4, wstęp i oprac. na podst. tłum. J. Czuja M. Ożóg, tekst łac. przygotował H. Pietras, Kraków 2011, s. 20 (Źródła Myśli Teologicznej, 63), łac.: „[...] Tamen placeat nobis invicem non tantum caritatis, verum etiam libertas amicitiae [...]".

75 J. N. D. Kelly, Hieronim: życie, pisma, spory, dz. cyt., s. 312. 
z herezją pelagiańską. Jednak nie można zapominać, że strategie tej walki przybierały nieco inną postać, tak jak inne były struktury osobowości Hieronima i Augustyna.

Tezy pelagiańskie głoszone były szeroko i cieszyły się dużym poparciem. Mogłoby się zdawać, że Augustyn nieco zbagatelizował ten problem. Nie zwrócił uwagi pojawienie się mnicha brytyjskiego w Rzymie (ok. 384) i głoszenie przezeń radykalnych poglądów. Biskup Hippony był wówczas zangażowany w spór z donatystami ${ }^{76}$. Dopiero rok 412 , gdy zapoznał się z decyzjami synodu w Kartaginie ${ }^{77}$, okazał się przełomowy, jeśli chodzi o zaangażowanie się Augustyna w walkę z kontrowersją. Rozpoczął kampanię przeciw pelagianom, pisząc listy, traktaty, głosząc kazania. Krytyką zostali objęci nie tylko zwolennicy Pelagiusza, ale i on sam.

Jednak, co warte podkreślenia, w przeciwieństwie do Hieronima, który od samego początku kontaktów z mnichem brytyjskim widział w głoszonych przezeń poglądach zagrożenie ${ }^{78}$, Augustyn do 415 roku twierdził, że nie może uwierzyć, aby takie poglądy były głoszone przez wzorowego chrześcijanina, jakim był Pelagiusz. Z charakterystycznym dla siebie taktem unikał konfrontacji z herezjarchą, jednak „miał świadomość jego odpowiedzialności”, czemu dał wyraz w uprzejmym liście (412 lub 413 rok) ${ }^{79}$. Prawdopodobnie na tym etapie, ze względu na znamienitych patronów Pelagiusza i szacunek dla niego, Augustyn wolał nie wciągać go w spór ${ }^{80}$.

W Jerozolimie Pelagiusz trafił na podatny grunt, bowiem tradycja Wschodu podkreślała bardziej znaczenie wolnej woli, dlatego też spotkał się tu z większą

76 K. Obrycki, Wstęp, dz. cyt., s. 193-194; J. N. D. Kelly, Hieronim: życie, pisma, spory, dz. cyt., s. 354 .

77 K. Obrycki, Wstęp, dz. cyt., s. 194; więcej na temat kwestii Augustyn-Pelagiusz-łaska: G. Madec, La patria e la via. Cristo nella vita e nel pensiero di S. Agostino, Roma 1993, s. 233-241.

78 W. Myszor twierdzi, iż było inaczej - według niego to właśnie Hieronim nie dostrzegł wyraźnego „niebezpieczeństwa nowej nauki”; Wstęp, dz. cyt., s. 21.

${ }^{79}$ „Panu najmilszemu i najbardziej oczekiwanemu, bratu Pelagiuszowi, pozdrowienie w Panu przesyła Augustyn. Dziękuję bardzo, że raczyłeś ucieszyć mnie swoim pismem i upewnić o waszym zbawieniu. Niech Pan zwróci Ci dobra, dzięki którym jesteś dobry [...]. Ja zaś, chociaż nie uznaję Twoich pochwał wobec mnie, to jednak nie mogę być niewdzięczny na Twe życzliwe uczucie względem mej małości [...]. Panie najmilszy i najbardziej oczekiwany Bracie. Pamiętając o nas, obyś przede wszystkim podobał się Panu". Fragment Listu 146 [w:] Augustyn z Hippony, Dzieje procesu Pelagiusza, dz. cyt., s. 259; Patrologia Latina 44, s. 319-360.

J. N. D. Kelly, Hieronim: życie, pisma, spory, dz. cyt., s. 354-355. 
przychylnością (początkowo) niż w Afryce Północnej. Jednak Hieronim, mimo iż tolerował (do czasu) Pelagiusza, nie potrafił ujarzmić w sobie dawnych wrogości, a także ducha Zachodu ${ }^{81}$. Jego pisma przez kolejne lata były pełne wulgarnych sformułowań, epitetów, szyderstw pod adresem Pelagiusza. Jednakże zaczepki miały obustronny charakter - mnich brytyjski zarzucił Hieronimowi, że przejawia tendencje orygenistyczne, podczas gdy był on ich stanowczym przeciwnikiem. Wydaje się, iż Pelagiusz chciał odwrócić sytuację, bowiem za to najczęściej Hieronim go atakował ${ }^{82}$. Odżył również spór odnośnie do poglądów na temat małżeństwa. Pelagiusz wyciągnął stare argumenty, oparł się na poglądach Hieronima głoszonych w Przeciw Jowinianowi ${ }^{33}$.

Najistotniejszy jednak w tym sporze jest fakt, iż mimo osobistych animozji i przytyków chodziło w gruncie rzeczy o poważną rozbieżność w poglądach teologicznych. I mimo iż Hieronimowi można zarzucić wiele rzeczy (ujawniających się już w antypelagiańskich listach - 130 do Demetrias ${ }^{84}$ i 133 do Ktezyfonta ${ }^{85}$ ), m.in. bezpodstawne zarzuty dotyczące zakorzenienia pelagianizmu w gnostycyzmie czy manicheizmie, zrównanie doktryny o możliwości życia bez grzechu z grecką apatheia ${ }^{86}$, to jednak nie można odmówić mu intuicji i czujności. Mając na uwadze jego bezkompromisowość (wyrażaną co prawda na różne sposoby) oraz szybkość reakcji ${ }^{87}$, można wybaczyć mu owe "grzeszki”. Jeszcze przed synodem w Diospolis ${ }^{88}$ Hieronim wyraził swój stanowczy głos w walce z pelagianizmem, publikując Dialog przeciw pelagianom, co spotkało się z gwałtowną reakcją zwolenników Pelagiusza, któ-

81 J. N. D. Kelly, Hieronim: życie, pisma, spory, dz. cyt., s. 354-355.

82 J. N. D. Kelly, Hieronim: życie, pisma, spory, dz. cyt., s. 354-355.

83 Więcej na ten temat zobacz: Y. M. Duval, Pélage est-il le censeur inconnu de l'Adversus Jovinianum à Rome en 393? ou: du „portrait-robot” de l'hérétique chez S. Jérôme, „Revue d'Histoire Ecclésiastique Louvain" 75 (1980) 3-4, s. 525-557; Y. M. Duval, L'affaire Jovinien. D'une crise de la société romaine à une crise de la pensée chrétienne à la fin du IVè et au début du Vè siècle, Roma 2003 (Studia Ephemeridis Augustinianum).

84 Św. Hieronim, List 130, PAX 3/3, s. 304-330.

85 Św. Hieronim, List 133, PAX 3/3, s. 367-386.

86 Św. Hieronim, Żywoty mnichów. Dialog przeciw pelagianom, dz. cyt., s. 69.

87 Zdaniem J. N. D. Kelly'ego Hieronim zmierzył się z Pelagiuszem co najmniej rok wcześniej niż Augustyn (De natura et gratia, powstałe w $415 \mathrm{roku}$ ), J. N. D. Kelly, Hieronim: życie, pisma, spory, dz. cyt., s. 360 .

88 Według W. Myszora w 2. połowie 415; Wstęp, [w:] św. Hieronim, Żywoty mnichów. Dialog przeciw pelagianom, dz. cyt., s. 17. 
rzy dokonali pogromu swoich przeciwników i wielkich zniszczeń w klasztorach betlejemskich. Rok 417 przyniósł ostateczne potępienie herezji, głównie za sprawą wpływów biskupów Afryki Północnej (na czele z Augustynem ${ }^{89}$ ). Sam dialog jest cennym źródłem patrystycznym, jak również (co istotne!) - jedną z wcześniejszych pozaaugustyńskich odpowiedzi na pelagianizm. Augustyn niewątpliwie miał jakiś wpływ na Hieronima ${ }^{90}$, jednak trzeba pamiętać, że ostatnie słowo należało do samego autora, który chciał rozprawić się również ze szczególnie tępionymi przez siebie poglądami. Co znamienne, cały tekst przeniknięty jest specyficznym podejściem Hieronima do kwestii ascezy i surowości życia z nią związanej, toteż niektóre twierdzenia można właściwie interpretować, mając na uwadze ten aspekt ${ }^{91}$.

Autor widzi świat pozbawiony odcieni, nie ma według niego sytuacji pośrednich. Biało-czarna wizja człowieka i rzeczywistości, w jakiej dokonuje on wyborów, uwarunkowana jest doświadczeniami Hieronima. Podczas pobytu w Rzymie miał okazję zaobserwować, iż życie (nawet duchownych) dalece odbiega od chrześcijańskiego ideału. Ponadto był świadom, że ten stan rzeczy zmierza ku gorszemu obrazowi świata. Trudno zatem się dziwić dającemu się zaobserwować na kartach Dialogu przeciw pelagianom brakowi rozróżnień. Można zauważyć brak odróżnienia grzechu ciężkiego od tego o lżejszej materii i rad ewangelicznych od przykazań; już samo wypowiedzenie żartu zdaniem Hieronima zasługuje na wymierzenie kary ${ }^{92}$. Każde odstępstwo jest czymś złym i takim winno być nazwane.

Stąd pesymistyczny obraz natury ludzkiej i propagowanie rygoryzmu, mającego ujarzmić niepokorne zamiary człowieka. Subtelne rozróżnienia

89 Augustyn z Hippony, Dzieje procesu Pelagiusza, 65: „Cieszmy się więc, że tak wielkie zło nowej herezji zostało wyrokiem potępione. Dziękujmy za to Bogu i wychwalajmy Go, bez względu na to, jak Celestiusz przedstawił [te twierdzenia], Pelagiusz zaś zrozumiał lub nie zrozumiał", s. 271. Więcej na temat kościelnego odrzucenia doktryny pelagiańskiej zob.: G. Greshake, Gnade als konkrete Freiheit. Eine Untersuchung zur Gnadenlehre des Pelagius, Grünewald, Mainz 1972; O. Wermelinger: Rom und Pelagius. Die theologische Position der römischen Bischöfe im pelagianischen Streit in den Jahren 411-432, Stuttgart 1975; M. Vessey: "Opus imperfectum“. Augustine and his readers, 426-435 A. D., „Vigiliae Christianae” 52 (1998) nr 3, s. 264-285.

90 Po publikacji dialog odniósł niemały sukces; Augustyn chwalił go za przejrzysty, pełen uroku styl oraz pewność doktryny; K. Obrycki, Wstẹp, dz. cyt., s. 197.

${ }_{91}$ W. Myszor, Wstęp, dz. cyt., s. 18.

${ }_{92}$ Św. Hieronim, Żywoty mnichów. Dialog przeciw pelagianom, dz. cyt., II. 5, s. 128; II. 11, s. 136. 
zupełnie nie pasują do stylu Hieronima. Jednakowoż wydaje się, że zapał, z którym głosił on swe poglądy, w pewien sposób rekompensuje brak delikatności w jego wywodach moralizatorskich. Tym, co może wydawać się już bardziej niebezpieczne teologicznie, jest ta sama skłonność, ale na polu ściśle dogmatycznym. Mimo iż Hieronim chciał się szczegółowo rozprawić „ze wszystkimi twierdzeniami tych, którzy sławią apatheia ${ }^{93 ”, ~ c o ~ z a p o-~}$ wiada już w Liście do Ktezyfonta ${ }^{94}$, trudno oprzeć się wrażeniu, że selektywność tematów zagościła na kartach polemicznego dzieła Hieronimowego. Najwięcej uwagi poświęca poglądom pelagiańskim, jakoby człowiek mógł, jeśli zechce, żyć bez grzechu, oraz twierdzeniu o przykazaniach Bożych, że są łatwe do wypełnienia. Te właśnie zagadnienia uczynił swoistym lejtmotywem w dziele ${ }^{95}$. Prawdopodobnie wymienione zagadnienia były poruszane przez Orozjusza na synodzie jerozolimskim ${ }^{96}$.

Trzeba zauważyć, że Hieronim próbuje podważaćnaukę pelagiańską w sposób odmienny od metody Augustyna. Biskup Hippony kwestionował racjonalność herezji. Uważał, że sprzeczność herezji pelagiańskiej zachodzi na płaszczyźnie rozumowej, natomiast Hieronim akcentował bardziej sprzeczność z objawieniem Bożym. Dowodem takiego spojrzenia jest choćby ogrom cytatów z Pisma Świętego, który można uznać za dowód jego wielkiej wiedzy.Jednak pewien automatyzm cytowania sprawia, że lektura staje się dość uciążliwa ${ }^{97}$. Trzeba przy tym dodać, że dużą rolę pełni w Dialogu... nauka św. Pawła ${ }^{98}$. Hieronim dość często powołuje się na Apostoła Narodów, używając przy tym pięknych epitetów pod jego adresem ${ }^{99}$. Nie można jednak powiedzieć, by biegłość w cytowaniu świętych ksiąg przełożyła się na wnikliwą analizę relacji wolnej woli i łaski ${ }^{100}$.

\footnotetext{
93 Św. Hieronim, Prolog, [w:] św. Hieronim, Żywoty mnichów. Dialog przeciw pelagianom, dz. cyt., s. 69.

${ }_{94}$ Św. Hieronim, List 133, PAX 3/3, s. 385-386; Patrologia Latina 22, k. 1147-1161.

95 Np. Dialog..., s. 73-120. Tak naprawdę cała Księga pierwsza dotyczy tych zagadnień.

96 W. Myszor, Wstęp, dz. cyt., s. 18.

97 Pewne sekcje Hieronimowego Dialogu są wręcz kompilacją cytatów z Pisma Świętego, jak choćby: s. 110-120, 125-167.

98 Św. Hieronim, Żywoty mnichów. Dialog przeciw pelagianom, dz. cyt., II.8-10, s. 133-135.

99 Św. Hieronim, Żywoty mnichów. Dialog przeciw pelagianom, dz. cyt., III.17-18, s. 191: „ewangeliczna tuba”, „nauczyciel narodów”, „złote naczynie, jaśniejące na całym świecie”.

100 W. Myszor, Wstęp, dz. cyt., s. 19.
} 
Co więcej, niektóre wypowiedzi Hieronima można zaliczyć do bliskich późniejszemu zjawisku - semipelagianizmowi. Mimo iż Hieronim wpisuje się w ogólną tradycję uznającą konieczność istnienia do zbawienia obu czynników - wolnej woli i łaski, to jednak ustalenie pierwszeństwa w czasie któregoś z nich sprawia mu problem. I w tym przejawia się jego niekonsekwencja, sprzeczność. Można znaleźć cytaty dające się zakwalifikować z jednej strony jako semipelagiańskie: „Zgadzamy się więc z tym, że co do dobrych czynów, poza własną wolą, opieramy się na pomocy Boga, a w złych na szatana”, „od nas zależy chcieć i biec”"101; z drugiej - jako antagonistyczne (posługując się cytatem z J 5, 30): „Sam z siebie, mówi (Pan), nic uczynić nie mogę, lecz czynię według tego, co słyszę" ${ }^{102}$.

Niekonsekwencja Hieronima ujawnia się również w niespełnionej obietnicy dotyczącej głębszego rozwinięcia zależności pelagianizm - orygenizm ${ }^{103}$. Miast tego próbuje raczej udowodnić, że pelagianie są mentalnymi dziećmi Jowiniana ${ }^{104}$. Jednak, jak utrzymuje John Norman Davidson Kelly, założenie to wydaje się zupełnie nieprawdopodobne, bowiem Jowinian wykluczał całkowitą możliwość popełniania grzechów przez chrześcijan. Może tu chodzić ponownie o urażoną dumę Hieronima, pamiętającego dawną krytykę jego lekceważącego stosunku do małżeństwa ze strony Pelagiusza ${ }^{105}$. Hieronim, podobnie jak Augustyn, dostrzegł, jakie mogą być konsekwencje, jeśli człowiek zechce wyeliminować ze swojej egzystencji wielką rolę łaski Bożej. Świadom własnych słabości, w czym również był spójny z biskupem Hippony, podkreślał, że to praktyki ascetyczne (grzesznych mnichów) wraz z łaską Bożą pozwalają budować ideał chrześcijanina. Paradoksalnie pesymi-

101 Św. Hieronim, Żywoty mnichów. Dialog przeciw pelagianom, dz. cyt., I.1-2.5, ss. 74 i 76.

102 Św. Hieronim, Żywoty mnichów. Dialog przeciw pelagianom, dz. cyt., II.17, s. 145.

103 W. Myszor, Wstęp, dz. cyt., s. 20, twierdzi, że „podobieństwo pelagianizmu do nauki Orygenesa mogło być tylko powierzchowne. Nie może być mowy o jakimś głębszym związku". Natomiast J. N. D. Kelly, Hieronim: życie, pisma, spory, dz. cyt., s. 360, uważa, iż Hieronim [w Liście do Ktezyfonta] „miał całkowitą rację, wykazując wpływ, jaki na myślenie Pelagiusza [...] wywarła nauka Orygenesa”.

104 Św. Hieronim, Żywoty mnichów. Dialog przeciw pelagianom, dz. cyt., III. 1, s. 168. „Czy nie wstydzisz się trzymać odrzuconej i potępionej nauki Jowiniana?”; Liber Tertius, 781, k. 595: „A.: Non erubescis explosam atque damnatam Joviniani sententiam sequi?".

105 J. N. D. Kelly, Hieronim: życie, pisma, spory, dz. cyt., s. 360-361. 
styczna wizja człowieka jest lepszym punktem wyjścia do rozważań o nim. Bowiem gdzie grzech, tam i łaska. Nieskończenie większa łaska.

\section{Podejście Hieronima do kontrowersji pelagiańskiej w kontekście zachodniej teologii łaski}

Hieronim, walcząc z pelagianizmem, wpisywał się w ortodoksyjny nurt teologii łaski propagowanej w Kościele zachodnim przez Augustyna, biskupa afrykańskiego Hippo Regius. Nie odkrył w tej materii niczego nowego. Różnice dotyczyły głównie nie tyle samej doktryny, ile raczej sposobu jej aplikowania (o czym była już mowa). Teren walki z pelagianami implikował inne akcenty w podejściu do kontrowersji, ale nie do tego stopnia, aby ją zaakceptować. Chodzi głównie o podatność teologii Wschodu na podkreślanie znaczenia wolnej woli, co w środowiskach mniszych wydawało się uzasadnione. Stąd początkowo właśnie w Jerozolimie Pelagiusz znalazł bardziej podatny grunt do głoszenia swych racji ${ }^{106}$. Imponował ascetycznym pragnieniem doskonałości. Przebywając w Kartaginie (ok. 409, 410 roku), nie mógł liczyć na szeroką aprobatę swych kontrowersyjnych poglądów. Kościół afrykański bowiem w IV wieku zmagał się z donatystami, którzy, nomen omen, podkreślali wagę dobrych uczynków, podkreślając przy tym świętość członków swego Kościoła ${ }^{107}$.

Z jednej strony ojcowie afrykańscy byli już wyczuleni na każde odstępstwo, przeakcentowanie, z drugiej jednak - paradoksalnie - mogła zostać początkowo uśpiona ich czujność (szczególnie Augustyna), który nie dowierzał, że świetnie wykształcony i nienaganny moralnie mnich może głosić tak irracjonalne poglądy ${ }^{108}$. Zresztą również Hieronim, a wraz z nim biskup Jan i rzesze pobożnych kobiet na krótki czas , na samym początku pobytu mnicha w Jerozolimie, zostali zwiedzeni przez Pelagiusza ${ }^{109}$. Jednak liczne zale-

106 J. N. D. Kelly, Hieronim: życie, pisma, spory, dz. cyt., s. 355.

107 K. Burczak, Biskupi afrykańscy wobec herezji pelagianizmu, „Vox Patrum”, 22 (2002) nr 4243, s. 441.

108 J. N. D. Kelly, Hieronim: życie, pisma, spory, dz. cyt., s. 354.

109 J. N. D. Kelly, Hieronim: życie, pisma, spory, dz. cyt., s. 355. 
ty postępowania Pelagiusza nie były w stanie ostatecznie przesłonić daleko idących odstępstw natury teologicznej.

Walka dwu wielkich ojców Kościoła z herezją toczyła się na frontach Wschodu i Zachodu ${ }^{110}$. Jeden cel, nieco odmienne taktyki. Hieronim, zafascynowany ascetycznym stylem życia, balansował myślowo między Wschodem a Zachodem, jednakże trudno zaprzeczyć, że mentalność zachodnia była mu bliższa, transponował zatem idee Zachodu na teren Jerozolimy. Nie da się ukryć, że to Augustyn był odnowicielem teologicznej nauki o łasce (zaczerpniętej ze spuścizny św. Pawła ${ }^{111}$. W tej materii nieco starszy Hieronim mógł się odwoływać do autorytetu biskupa Hippony. We wschodniej teologii przedaugustyńskiej można odnaleźć inne idee ${ }^{112}$. Jego nauka o łasce to było novum, swoista odpowiedź wiary na specyficzną sytuację Zachodu ${ }^{113}$, aktualizacja myśli Pawłowej, nowość tej aktualizacji. Augustyn jako okręt flagowy biskupów afrykańskich (wraz z Aureliuszem - biskupem Kartaginy) w walce z pelagianizmem, dzięki wnikliwości myślenia teologicznego i zdecydowaniu obronił Kościół przed kolejną herezją. Zwrócenie się do papieża Zozyma z prośbą o wydanie przezeń autorytatywnego potwierdzenia ustaleń synodu w Kartaginie (418) było przełomem ${ }^{114}$.

Trzeba jednak dodać, że poglądy Augustyna na łaskę nie tyle ewoluowały, ile często były ze sobą sprzeczne. Najpierw w reakcji na manicheizm w sposób jednostronny akcentował on ludzką wolność, co doprowadziło go do przyjęcia idei predestynacji, opartej na przewidywaniu zasług człowieka. Lata 396-397 to przełomowy czas dla Augustyna. Łaska Boża stanie się odtąd dla młodego biskupa Hippony pojęciem kluczowym, a predestynacja oparta będzie już jedynie na odwiecznej decyzji Boga. Apogeum tego okresu to czas walki z pelagianizmem. Wówczas Augustyn ostatecznie przypieczętowuje swe poglądy, w których łaska i predestynacja pełnią dominującą funkcję $e^{115}$.

\footnotetext{
110 G. Kraus, Nauka o łasce: zbawienie jako łaska, przekł. W. Szymona, Kraków 1999, s. 101.

111 G. Greshake, Wprowadzenie do nauki o łasce, przekł. S. Jopek, Kraków 2005, s. 45.

112 Por. M. Przyszychowska, Nauka o łasce w dziełach św. Grzegorza z Nyssy, Kraków 2010.

113 G. Greshake, Wprowadzenie do nauki o łasce, dz. cyt., s. 45.

114 K. Burczak, Biskupi afrykańscy wobec herezji pelagianizmu, dz. cyt., s. 444.

115 G. Kraus, Nauka o łasce: zbawienie jako łaska, dz. cyt., s. 107.
} 
Dzieje sporu o łaskę (V/VI wiek) dobrze ilustruje zestawienie dokonane przez Georga Krausa ${ }^{116}$ :

\begin{tabular}{|c|c|c|}
\hline Akt & Data & Wydarzenie \\
\hline I. 1 & przed 396 & $\begin{array}{l}\text { 1. Augustyn, I okres: źródłem grzechu jest wolna wola człowieka (przeciw } \\
\text { manichejczykom) - stąd: predestynacja warunkowa; }\end{array}$ \\
\hline I. 2 & $396 / 397$ & $\begin{array}{l}\text { 2. II okres: wola grzesznika ma tylko in abstracto możność czynienia dobra. } \\
\text { Także dobre akty woli musi wspierać łaska - stąd predestynacja bezwa- } \\
\text { runkowa, zależna wyłącznie od Bożej decyzji. }\end{array}$ \\
\hline II & $411-415$ & $\begin{array}{l}\text { W pierwszej (pośredniej) konfrontacji z Pelagiuszem i Celestiuszem Au- } \\
\text { gustyn rozbudowuje swoją teorię (obrona doktryny grzechu pierworod- } \\
\text { nego, pogłębienie nauki o concupiscentia, wolność woli - uległość porusze- } \\
\text { niom łaski). }\end{array}$ \\
\hline III & od 415 & $\begin{array}{l}\text { Po bezpośredniej konfrontacji z Pelagiuszem Augustyn zaostrza swój po- } \\
\text { gląd na grzech pierworodny i concupiscentia. }\end{array}$ \\
\hline IV & 418 & $\begin{array}{l}\text { Na synodzie w Kartaginie Augustyn doprowadza do potępienia Celestiu- } \\
\text { sza (DH 222-230); potwierdzenie tej decyzji przez papieża Zozyma (DH 231). }\end{array}$ \\
\hline V & $425-429$ & $\begin{array}{l}\text { Opozycja semipelagian. Przeciw Augustynowi twierdzą oni, że początek } \\
\text { wiary (initium fideii) jest dziełem woli (chory musi sam przywołać lekarza); } \\
\text { człowiek może dochować wierności otrzymanej łasce. Augustyn stawia tezy } \\
\text { jeszcze mocniej akcentujące wyłączność Boga w działaniu: Bóg predestynu- } \\
\text { je pozytywnie do zbawienia, a do potępienia negatywnie, zgodnie ze swoim } \\
\text { tajemnym zamysłem. Predestynacja pozytywna jest darmowa, niezawod- } \\
\text { na i jednostkowa; przeznaczenie negatywne wynika z absolutnej sprawied- } \\
\text { liwości Boga. }\end{array}$ \\
\hline VI & $430-529$ & Trzy etapy sporów semipelagiańskich po śmierci Augustyna: \\
\hline VI. 1 & $430-440$ & $\begin{array}{l}\text { 1. Prosper z Akwitanii systematyzuje augustynizm w Indiculus (DH 239- } \\
\text { 249: łaska dokonuje initium fidei; grzech niweczy wolność czynienia do- } \\
\text { bra; predestynacja do zbawienia; przewidywanie potępienia - stąd po- } \\
\text { wszechna zbawcza wola Boża); }\end{array}$ \\
\hline VI. 2 & $470-471$ & 2. synod w Arles (proaugustyński); \\
\hline VI. 3 & 529 & $\begin{array}{l}\text { 3. Cezary z Arles, przy poparciu Rzymu, w Orange („Arausicanum II”: DH } \\
\text { 370-397; potwierdzenie przez papieża Bonifacego II: DH 398-400) oca- } \\
\text { la umiarkowaną formę augustynizmu: prymat łaski; utrata wolności na } \\
\text { skutek grzechu; initium fidei możliwe tylko dzięki łasce; odrzucenie nie- } \\
\text { których tez Augustyna (doktryny predestynacji, ścisłego związku grze- } \\
\text { chu z concupiscentia). }\end{array}$ \\
\hline
\end{tabular}


Można wnioskować, iż pojęcie łaski rozwijało się wraz z rozkwitem myśli przede wszystkim Augustyna, a później jego już nie tak nowatorskich następców. Niewątpliwie spory na tle dogmatycznym w znaczny sposób kształtowały mentalność, pobudzały do rozważania nauki wielkich ojców Kościoła. Konfrontacja z przeciwnikiem była na pewno budująca, implikowała powstawanie coraz ściślejszych pojęć. Zagadnienia, które zmuszały zarówno Augustyna, jak i Hieronima do wyrażania ortodoksyjnego stanowiska, ogniskują się wokół pojęcia łaski117. Pelagiusz twierdził, iż już sama natura ludzka jest łaską. Dzięki tej łasce człowiek jest zdolny do wypełniania wyrytego w sercu prawa Bożego. Pogląd ten ujął w lapidarnej formule: posse non peccandi (ludzie mają naturalną możność niegrzeszenia). Twierdzenie to było bardzo ostro odebrane przez Augustyna i Hieronima. Pelagiusz bowiem już samej ludzkiej naturze przyznaje możność życia bez grzechu, jeśli tylko człowiek potrafi korzystać z rozumu i wolnej woli, wybierając dobro zamiast zła. Dla Augustyna, jak i Hieronima było to nie do pogodzenia, ponieważ ludzka natura jawiła się jako przeciwieństwo łaski Bożej ${ }^{118}$.

Jednak nie zauważono, że Pelagiusz wyróżniał również drugą podstawową łaskę, daną przy stworzeniu. Stwórca obdarowuje ludzi aktualną pomocą (auxilium, adiutorium), której dostępują wszyscy. Jest to rodzaj łaski oświecającej, pozwalającej poznać dobro. Na tej podstawie Pelagiusz twierdzi, że nawet poganie mogą osiągnąć zbawienie. Postaci Starego Testamentu (Abel, Noe, Hiob, Abraham) stanowią egzemplifikację tego rozróżnienia ${ }^{119}$. Polemikę z tymi twierdzeniami można odnaleźć na kartach Dialogu przeciw pelagianom. Hieronim w swoim stylu zbija poglądy Pelagiusza, twierdząc, iż fragmenty z Pisma Świętego, na które Pelagiusz się powołuje, przytaczając przykłady sprawiedliwych, bezgrzesznych Starego Testamentu, świadczą o czymś innym. Twierdzi, że Pelagiusz nie ma racji, ponieważ nawet wymienione postaci nie były do końca idealne.

Zarówno Augustyn, jak i Hieronim mieli świadomość ułomności człowieka, co można dostrzec w ich twórczości. To wystarczyło Pelagiuszowi, aby inter-

117 Szerzej na temat grzechu pierworodnego i łaski zob.: L. F. Ladaria, Wprowadzenie do antropologii teologicznej, tłum. A. Baron, Kraków 1997, s. 83-100, 101-129.

118 G. Kraus, Nauka o łasce: zbawienie jako łaska, dz. cyt., s. 102-103.

119 G. Kraus, Nauka o łasce: zbawienie jako łaska, dz. cyt., s. 103. 
pretować owe pesymistyczne jego zdaniem twierdzenia (ukazujące człowieka jako istotę zagubioną i radykalnie niezdolną) w duchu manichejskim. Pelagiusz twierdził, iż Bóg w swej dobroci i sprawiedliwości niezmiennie daje ludziom możliwość spełniania Jego oczekiwań. Innymi słowy - wespół z ludzką naturą koegzystuje łaska. Człowiek ze swą naturą i imago Dei nieustannie doznaje łaski, jest w polu jej działania ${ }^{120}$. Z kolei optyka Augustynowa i Hieronimowa są zgoła inne. Fakt, że człowiek doświadcza niemożności wypełniania Bożych wymagań, implikuje, obnaża jego konieczność zdania się na łaskę Boga.

Ludzie niejako zdani są na tę siłę wewnętrzną, której dysponentem jest Stwórca. To On decyduje, czy i komu jej udzielić. Na tej podstawie nietrudno wnioskować, iż tych dwóch punktów widzenia nie sposób ze sobą pogodzić. Sztandarowe słowa Augustyna - „Daj to, co nakazujesz, każ to, czego chcesz" - były dla Pelagiusza nie do zaakceptowania. Widział w nich bowiem łatwą wymówkę, by człowiek nie podejmował jakiegokolwiek wysiłku. Zdaniem Pelagiusza Stwórca już „dał”, a człowiekowi pozostaje tylko działanie ${ }^{121}$.

Zarówno Hieronim, jak i Augustyn mieli podstawy ku temu, by propagować swe poglądy i bronić ich niestrudzenie. Biskup Hippony całe lata walczył o czystość w swym życiu ${ }^{122}$. Strydończyk napatrzył się na upadek obyczajów, szczególnie podczas pobytu w Rzymie. Sam również nie stronił w młodości od licznych uciech ${ }^{123}$. Pesymizm w postrzeganiu sił ludzkich, chcąc nie chcąc, wdarł się do ich koncepcji teologicznych ${ }^{124}$. Łaska w ich pojęciu to siła dana z zewnątrz, darowana od Boga. Nie jest ona daną na stałe własnością. To dar, o który trzeba zabiegać.

Podstawowa różnica ujęcia rysuje się następująco: od narodzin człowiek znajduje się w dynamice choroby duszy - twierdzi Augustyn, a za nim Hieronim; z kolei Pelagiusz umieszcza człowieka zawsze w dynamice łaski ${ }^{125}$. W Dialogu przeciw pelagianom znaleźć można wyraz Hieronimowego podejścia:

120 G. Greshake, Wprowadzenie do nauki o łasce, dz. cyt., s. 40.

121 G. Greshake, Wprowadzenie do nauki o tasce, dz. cyt., s. 40-41.

122 G. Greshake, Wprowadzenie do nauki o łasce, dz. cyt., s. 40-41.

123 W. Myszor, Wstęp, dz. cyt., s. 18; J. N. D. Kelly, Hieronim: życie, pisma, spory, dz. cyt., s. $28-$ 29; Hieronim ze Strydonu, List 2: „Ja jestem owym synem marnotrawnym [...], jeszcze nie zacząłem odpędzać od siebie pokus dawnej rozwiązłości [...]”, [w:] Hieronim ze Strydonu, Listy I, dz. cyt., s. 5-6.

124 L. F. Ladaria, Wprowadzenie do antropologii teologicznej, dz. cyt., s. 106-110.

125 G. Greshake, Wrowadzenie do nauki o łasce, dz. cyt., s. 41. 
Attyk: [...] Pokaż mi ciało, które nigdy nie chorowało i po długiej chorobie było pewne, iż stale będzie zdrowe, a pokażę ci duszę, która nigdy nie zgrzeszyła i żyjąc cnotliwie, potem nigdy nie zgrzeszy, zwłaszcza że występki są pobliskie cnót i jeśli nieco zboczysz, albo się zabłąkasz, lub w przepaść wpadniesz. [...] Do tego, co mogę, przez czas krótki, zmuszasz mnie, abym czynił zawsze. Mogę pościć, czuwać, chodzić, czytać, śpiewać, spać, ale czy zawsze? ${ }^{126}$.

Kolejny aspekt, na który warto zwrócić uwagę, to fakt, że Pelagiusz pojmuje naukę, prawo, przykład Chrystusa jako formy działania łaski Boga. Augustyn oraz Hieronim nie uważają tego za konkretne postaci łaski, również w sytuacji, gdy mają (prawo, nauka, przykład Jezusa) największe znaczenie dla obdarowanego łaską życia chrześcijanina. Dla człowieka, który nie został obdarowany, pozostają czymś zewnętrznym dopóty, dopóki nie zostanie mu wlana w serce odpowiednia łaska, tj. wyzwolenie ku miłości Boga i bliźniego ${ }^{127}$. Bez tego (miłości wewnętrznej) ideał imitatio Christi pozostaje niejako „uśpiony”, jest roszczeniem, a co za tym idzie - stanowi literę przynoszącą śmierć. Wniosek jest taki, iż człowiek w konfrontacji z łaską nie ma żadnego wyboru, bowiem jako istota grzeszna zawsze mógłby ją odrzucić. Innymi słowy - „Bóg musi najpierw z czystej łaskawości stworzyć w nas prawdziwą wolność bez naszego udziału" ${ }^{128}$.

Wyraz owych poglądów daje się zaobserwować w Dialogu...:

Attyk: [...] Nie uznajesz oddziaływania łaski Boga na poszczególne czyny, lecz o tyle ją uwzględniasz, o ile pozwala ci czynić to, co ci się podoba, odpowiednio do warunków i przepisów prawnych ${ }^{129}$.

126 Św. Hieronim, Żywoty mnichów. Dialog przeciw pelagianom, dz. cyt., III.11-12, s. 182; Liber Tertius, 794-795, k. 608: „A.: [...] Da mihi corpus quod nunquam languerit, aut quod post languorem perpetua sanitate securum sit: et dabo tibi animam quae nunquam peccaverit, nec post virtutes deinceps peccatura sit, praesertim cum vicina sint vitia virtutibus; et si paululum declinaveris, aut errandum tibi sit, aut in praeceps cadendum. [...] Nec quia ad breve poszum, coges me ut possim jugiter. Possum jejunare, vigilare, ambulare, legere, psallere, sedere, dormire, numquid in perpetuum?".

127 G. Greshake, Wprowadzenie do nauki o łasce, dz. cyt., s. 41.

128 G. Greshake, Wprowadzenie do nauki o łasce, dz. cyt., s. 41-42.

129 Św. Hieronim, Żywoty mnichów. Dialog przeciw pelagianom, dz. cyt., I.27-28, s. 103; Liber Primus, 723, k. 543-544 (Patrologia Latina, 23): „A.: [...] non absque Dei gratia, quomodo sentiri velis, ex hoc loco intelligitur, dum gratiam ejus non singular refers opera, sed ad conditionis ac legis et liberi arbitrii potestatem". 
oraz

Attyk: [...] Po długich bowiem rozprawach zostało ustalone, iż Bóg, który dzięki swej łasce dał nam wolną wolę, przy poszczególnych naszych czynnościach wspomaga nas i podtrzymuje ${ }^{130}$.

Ciekawe jest podejście Pelagiusza, wpisane w nurt wschodniej nauki o łasce, gdzie Bóg działa w historii i włącza wolność człowieka (nie do końca stłumioną) w aktywność na rzecz dobra, a człowiek wobec działań wychowawczych Boga może wypowiedzieć „nie”. Augustyn i Hieronim ustosunkowują się do tej kwestii w odmienny sposób. Twierdzą bowiem, że ludzkie pochodzenie od Adama implikuje fakt bycia pod wpływem grzechu w sposób bezwzględny, natomiast wybranie Boże sprawia, iż człowiek jest bezbłędnie pobudzany do miłości ${ }^{131}$. W konsekwencji powstaje pytanie - dylemat, znamienne dla zachodniej teologii łaski: przypisywanie Bogu czy też człowiekowi nadmiernego znaczenia w zbawczym wydarzeniu. Augustyn i Hieronim akcentują rolę Boga kosztem człowieka - Bóg sprawia wszystko, natomiast udział człowieka pozostaje nikły. Z kolei Pelagiusz przecenia rolę człowieka i jego wolności, natomiast rolę Stwórcy ogranicza do wyposażenia ludzi w środki konieczne do walki o zbawienie ${ }^{132}$.

Pelagiusz widział łaskę jako konkretnie przekazywaną przez Jezusa Chrystusa, Jego Kościół, relacje międzyludzkie jako czynnik zewnętrzny. Z kolei Augustynowa i Hieronimowa wizja ukazują łaskę w aspekcie wewnętrznym (Duch Święty, miłość Boga). Jest ona czymś dalece intymnym, bezpośrednim darem Boga odbieranym w ludzkiej subiektywności ${ }^{133}$.

Słowa 1 Kor 4, 7: „Cóż masz, czego byś nie otrzymał?”, to kluczowa myśl, punkt zapalny w myśleniu Augustynowo-Hieronimowym. Owo zdanie z Pisma Świętego pobudza do głębszej refleksji na temat relacji wolnej woli i łaski. Gdzie kończy się pole pierwszej, a zaczyna drugiej? Co leży w mocy łaski Bożej, a co - ludzkiej wolności? Mimo iż zagadnienie wydaje się dość

130 Św. Hieronim, Żywoty mnichów. Dialog przeciw pelagianom, dz. cyt., III.5-6, s. 174; Liber Tertius, 787, k. 601: „A.: [...] Hoc enim longa dissertatione conclusum est, ut gratia sua Dominus qua nobis concessit liberum arbitrium, in singulis operibus juvat atque sustentet".

131 G. Greshake, Wprowadzenie do nauki o łasce, dz. cyt., s. 42.

132 G. Greshake, Wprowadzenie do nauki o łasce, dz. cyt., s. 42-43.

133 G. Greshake, Wrowadzenie do nauki o łasce, dz. cyt., s. 43. 
trudne, to jednak ojcowie Zachodu przechylają szalę na rzecz łaski. Od czasu rozważań Augustynowych historia rozwoju doktryny o łasce w Kościele zachodnim kładzie nieustannie obok siebie te dwa pojęcia, stawia je na dwu równoległych torach, zmuszając do konkurencji. „Im większa łaska Boża, tym mniejsza ludzka wolność, i na odwrót"134.

Wolna wola i łaska - dwie przyczyny sprawcze. Która ma pierwszeństwo? Augustyn odpowiedział (a za nim Hieronim), iż wszelka zasługa jest uprzedzona przez łaskę. „Pan Bóg kocha żabę nie za to, że skrzeczy; żaba skrzeczy dlatego, że Pan Bóg ją kocha"135. Człowiek dzięki łasce jest pobudzany do aktywności, co więcej - zostaje obdarzony mocą do wytrwania w niej ${ }^{136}$. Ludzkie ,ja” wyraża swoje „chcenie”, otwarcie się na łaskę. „Bóg zaś w nas działa, wywołuje chęć i daje wykonanie"137.

\section{Zakończenie}

Hieronim, nazywany Doctor Maximus in exponendis Sacris Scripturis ${ }^{138}$, nie wykazał się oryginalnością w swojej krytyce doktryny pelagiańskiej. To, co Augustyn wyłożył w dziedzinie teologii łaski, Hieronim jedynie aplikował na potrzeby swoich rozważań. Hieronimowy Dialog przeciw pelagianom stanowi polemikę dogmatyczną, w której autor posługuje się swoistą formą dialogu sokratejskiego. Reasumując: wśród głównych wątków antypelagiańskich, które były przedmiotem dociekań Hieronimowych, na pierwszy plan wysuwają się następujące kwestie: możliwość grzechu po chrzcie, zagadnienie pomocy Bożej i jej konieczności w każdym działaniu człowieka, zdolność osiągnięcia prawdziwej doskonałości na ziemi oraz problem chrztu dzieci, prowokujący również rozważania na temat grzechu jako takiego.

134 G. Greshake, Wprowadzenie do nauki o łasce, dz. cyt., s. 38.

135 J. Twardowski, Wiersz z dedykacja, [w:] J. Twardowski, Rwane prosto z krzaka, Warszawa 1996, s. 185.

136 G. Kraus, Nauka o łasce: zbawienie jako łaska, dz. cyt., s. 111-112.

137 Św. Hieronim, Żywoty mnichów. Dialog przeciw pelagianom, dz. cyt., II.10, s. 135; Hieronim parafrazuje Flp 2, 13; Liber Secundus, 752, k. 570 (Patrologia Latina, 23): „A.: Haec cuncta percurro, ut ostendam a nullo legem esse completam, et per legem mandata omnia quae continentur in lege. Deus est enim qui operator in nobis, et velle et perficere".

138 T. Jelonek, Hieronim, dz. cyt., s. 99. 
Rozważania Strydończyka zdają się implikować pewne wnioski dotyczące specyfiki jego dociekań, mianowicie: brak rozróżnień (uwarunkowany jego wcześniejszymi doświadczeniami życiowymi), który daje się zaobserwować na kartach Dialogu przeciw pelagianom, np.: grzech ciężki a grzech lekki; rady ewangeliczne a przykazania; uznanie żartu za coś wymagającego wymierzenia kary. Stąd również wynika pesymistyczny obraz natury ludzkiej i propagowany przezeń rygoryzm. Kolejna kwestia warta podkreślenia - koncentracja Hieronima na poglądzie pelagiańskim, że człowiek może, jeśli zechce, żyć bez grzechu. Jest to swoisty lejtmotyw jego dociekań. Hieronim podchodzi do nauki pelagian z orężem objawienia Bożego (ogrom cytatów), odmiennie aniżeli Augustyn, który największy nacisk kładzie na kwestionowanie racjonalności herezji.

Ponadto wybrane wypowiedzi Hieronima nasuwają skojarzenia z późniejszym zjawiskiem - semipelagianizmem. Hieronim gubi się w ustalaniu pierwszeństwa czasowego wolnej woli i łaski. O ile nie podaje w wątpliwość konieczności ich koegzystencji, o tyle hierarchizacja w czasie jest wielce problematyczna. Co rusz zdaje się dochodzić do głosu niekonsekwencja autora Dialogu przeciw pelagianom. Najpierw w kontekście stwierdzeń o zabarwieniu semipelagiańskim, później - w niespełnionej obietnicy dotyczącej rozwinięcia zależności pelagianizm-orygenizm. W zamian za to oferuje czytelnikowi liczne próby powiązań pelagian z Jowinianem.

Hieronim nie był specjalnie nowatorski, jeśli chodzi o zagadnienie teologii łaski. Wpisywał się świetnie w nurt teologii Zachodu. Inne było u niego jedynie rozłożenie akcentów, zastosowanie doktryny. Wynikało to choćby z uwarunkowań miejsca, , w których przyszło mu działać - mnisze środowiska Wschodu siłą rzeczy narzucały określony sposób prowadzenia rozważań. Zatem zanurzony głęboko w mentalności zachodniej dostosowuje tę doktrynę na potrzeby specyfiki myślenia Jerozolimy. Warto podkreślić, że Strydończyk od samego początku był wyczulony na poglądy mnicha brytyjskiego, utożsamianego przez wieki z herezją pelagiańską - burzliwym sporem na Zachodzie przełomu IV i V wieku, mającym swoje reperkusje w myśli teologicznej po dziś dzieńn ${ }^{139}$.

139 A. Baron, Spór o Pawła, spór o człowieka czy spór o Boga? Refleksje na marginesie kontrowersji pelagiańskiej, dz. cyt., s. 9. 


\section{Summary}

\section{Jerome's criticism of pelagianism in Dialogus contra pelagianos}

Saint Jerome in the battle of pelagianism not differed essentially from other theologians of grace, for example St. Augustine. However Vulgata's author had the opportunity to meet with Pelagius earlier than Augustine. He doesn't avoid controversial statements, especially in disputes with pelagians. At the same time he was master of the beautiful expressions. Many times he was inconsistent in theological reflection. Probably therefore he doesn't enjoy great popularity between contemporary theologians. This publication, based on the Dialogus contra pelagianos and Jerome's Letters reaction against pelagianism and Pelagius. First of all, based on the Dialogus contra pelagianos and the Jerome's Letters, is an attempt to show the Jerome's reaction against pelagianism and Pelagius in the first half on $5^{\text {th }}$ century. Using the method theological, historical and linguistical. First, I want to emphasize the most important theological problems about which he wrote. Next - I want to talk about distinguishing marks his criticism of pelagianism and show this criticism in context theology of grace West Church (Latin Church) the first half of the $5^{\text {th }}$ century.

Keywords: critic, pelagianism, st. Jerome, Pelagius

\section{Hieronimowa krytyka pelagianizmu w Dialogu przeciw pelagianom}

Sam fakt krytyki zjawiska pelagianizmu przez Hieronima nie był niczym odkrywczym, oryginalnym. Idzie on bowiem po linii, którą prezentuje choćby św. Augustyn. Jednakowoż na szczególną uwagę zasługuje sposób, w jaki to czyni, specyfika jego podejścia. Strydończyk miał okazję zetknąć się z Pelagiuszem i jego poglądami wcześniej aniżeli biskup Hippony i od samego początku był na nie wyczulony. W swoich wypowiedziach nie waha się używać kontrowersyjnych, mocnych argumentów. Jednocześnie jest mistrzem pięknych, kwiecistych sformułowań. Wielokrotnie jest w swych teologicznych rozważaniach niekonsekwentny. Prawdopodobnie dlatego nie cieszy się dużą popularnością wśród współczesnych teologów. Niniejsza publikacja jest próbą ukazania reakcji Hieronima na herezję pelagiańską i samego Pelagiusza przede wszystkim w oparciu o Dialog przeciw pelagianom oraz Listy, z zastosowaniem metod teologicznej, historycznej oraz filologicznej. W pierwszej kolejności omówiono najważniejsze problemy teologiczne, o których pisał Strydończyk. Następnie nakreślono cechy szczególne podjętej przez niego krytyki pelagianizmu, po czym ukazano tę krytykę w kontekście szeroko rozumianego nurtu teologii łaski w Kościele zachodnim pierwszej połowy V wieku.

Słowa kluczowe: krytyka, pelagianizm, św. Hieronim, Pelagiusz 


\section{Bibliografia}

Augustyn z Hippony, Grzech pierworodny. Dzieje procesu Pelagiusza, Kraków 1999 (Źródła Myśli Teologicznej, 12).

Augustyn z Hippony, Listy, tłum. W. Eborowicz, Pelplin 1991.

Baron A., Spór o Pawła, spór o człowieka czy spór o Boga? Refleksje na marginesie kontrowersji pelagiańskiej, [w:] Pelagiusz, Komentarz do Listu św. Pawła do Rzymian, Kraków 1999, s. 5-167 (Źródła Myśli Teologicznej, 15).

Burczak K., Biskupi afrykańscy wobec herezji pelagianizmu, „Vox Patrum” 22 (2002) 4243, s. 441.

Czuj J., Przedmowa, [w:] św. Hieronim, Listy, 1, tłum. J. Czuj, Warszawa 1952, s. 5-22.

Duval Y. M., L'affaire Jovinien. D'une crise de la société romaine à une crise de la pensée chrétienne à la fin du IVè et au début du Vè siècle, Roma 2003 (Studia Ephemeridis Augustinianum).

Duval Y. M., Pélage est-il le censeur inconnu de l'Adversus Jovinianum à Rome en 393? ou: du „portrait-robot” de l'hérétique chez S. Jérôme, „Revue d'Histoire Ecclésiastique Louvain” 75 (1980) 3-4, s. 525-557.

Greshake G., Gnade als konkrete Freiheit. Eine Untersuchung zur Gnadenlehre des Pelagius, Mainz 1972.

Greshake G., Wprowadzenie do nauki o łasce, przekł. S. Jopek, Kraków 2005.

Hieronim św., Listy, 1-3, przeł. J. Czuj, Warszawa 1952-1954.

Hieronim św., Żywoty mnichów. Dialog przeciw pelagianom, tłum. W. Szołdrski, Warszawa 1973 (Pisma Starochrześcijańskich Pisarzy, 10).

Hieronim ze Strydonu, Listy, t. 1-5, oprac. na podst. tłum. ks. J. Czuja, M. Ożóg; tekst łac. przygotował H. Pietras SJ, Kraków 2010-2013 (Źródła Myśli Teologicznej, 54, 55, 61, 63, 68).

Hieronymus Stridonensis, Dialogus adversus pelagianos, Parisiis 1845 (Patrologia Latina, 23).

Hieronymus Stridonensis, Epistula 133, k. 1147-1161, Parisiis 1859 (Patrologia Latina, 22). Jelonek T., Hieronim, Kraków 2003.

Kelly J. N. D., Hieronim: życie, pisma, spory, przeł. R. Wiśniewski, Warszawa 2003.

Kraus G., Nauka o łasce: zbawienie jako łaska, przekł. W. Szymona, Kraków 1999.

Ladaria L. F., Wprowadzenie do antropologii teologicznej, tłum. A. Baron, Kraków 1997.

Madec G., La patria e la via. Cristo nella vita e nel pensiero di S. Agostino, Roma 1993.

Myszor W., Wstęp, [w:] Św. Hieronim, Żywoty mnichów. Dialog przeciw pelagianom, tłum. W. Szołdrski, Warszawa 1973, s. 7-21 (Pisma Starochrześcijańskich Pisarzy, 10).

Obrycki K., Koncepcja grzechu pierworodnego u Pelagiusza na podstawie jego „Komentarza do Listu św. Pawła do Rzymian 5, 12-21", [w:] św. Augustyn, Grzech pierworodny. Dzieje procesu Pelagiusza, Kraków 1999, s. 177-185 (Źródła Myśli Teologicznej, 12).

Obrycki K., Wstęp, [w:] św. Augustyn, Grzech pierworodny. Dzieje procesu Pelagiusza, Kraków 1999, s. 193-209 (Źródła Myśli Teologicznej, 12).

Ożóg M., Wprowadzenie, [w:] Hieronim ze Strydonu, Listy 1, oprac. na podst. tłum. ks. J. Czuja M. Ożóg; tekst łac. przygotował H. Pietras SJ, Kraków 2010, Kraków 2010, s. 5-14 (Źródła Myśli Teologicznej, 54). 
Pelagiusz, Komentarz do Listu św. Pawła do Rzymian, Kraków 1999, s. 169-307 (Źródła Myśli Teologicznej, 15).

Przyszychowska M., Nauka o łasce w dziełach św. Grzegorza z Nyssy, Kraków 2010.

Twardowski J., Wiersz z dedykacja, [w:] J. Twardowski, Rwane prosto z krzaka, Warszawa 1996, s. 185.

Vessey M., „Opus imperfectum”. Augustine and his readers, 426-435 A. D., „Vigiliae Christianae" 52 (1998) 3, s. 264-285.

Wermelinger O., Rom und Pelagius. Die theologische Position der römischen Bischöfe im pelagianischen Streit in den Jahren 411-432, Stuttgart 1975. 